\title{
The Integration of Consonants in Greek Loanwords in Syriac
}

\author{
Aaron Michael Butts* \\ Department of Semitic and Egyptian Languages and Literatures, The Catholic \\ University of America, Washington, DC, USA \\ buttsa@cua.edu
}

\begin{abstract}
The present study analyses the integration of consonants in Greek loanwords in Syriac. It is shown that in the vast majority of cases each Greek consonantal phoneme is represented by a single consonant in Syriac. Correspondences that deviate from this are usually the result of one of two causes. First, a Koinē form of Greek, instead of Attic, likely served as the source for some of the words that prima facie seem to exhibit irregular correspondences. Second, some of the seemingly irregular correspondences are due to secondary developments in Syriac. This study is based on a corpus of more than eight hundred Greek loanwords and their derivatives found in pre-eighth-century Syriac texts that were not translated from Greek.
\end{abstract}

\section{Keywords}

Syriac - Greek - loanword - Latin - language contact

* I would like to thank the following people who helped with this study: Sebastian Brock (University of Oxford), Rebecca Hasselbach (University of Chicago), Kristian Heal (Brigham Young University), Lenore Grenoble (University of Chicago), George Kiraz (Beth Mardutho: Syriac Institute), Geoffrey Moseley (Yale University), Dennis Pardee (University of Chicago), Lucas Van Rompay (Duke University), as well as three anonymous reviewers. Abbreviations for lexicographical tools are explained at the end of the study in $\S 21$.

(C) AARON MICHAEL BUTTS, 2016 | DOI: 10.1163/17455227-01401004

This is an open access article distributed under the terms of the prevailing CC-BY license at the time of publication. 
Syriac underwent a prolonged period of contact with Greek. This resulted in, inter alia, a large number of Greek loanwords in Syriac. ${ }^{1}$ There are in fact more than eight hundred Greek loanwords attested in pre-eighth-century Syriac texts that were not translated from Greek. Many more are to be found in translated texts from this period or in later Syriac literature (whether translated or not). While a fair amount of literature has been devoted to Greek loanwords in Syriac, ${ }^{2}$ very little attention has thus far been paid to their phonological integration. In the standard grammar of Syriac, Nöldeke discusses this topic in only a handful of paragraphs. ${ }^{3}$ Other grammars, such as by Brockelmann and Muraoka, offer even fewer remarks. ${ }^{4}$ In the only monographic study of Greek loanwords in Syriac, Schall makes a number of passing references to phonological integration, ${ }^{5}$ but he never provides a systematic treatment. More recently, Brock and Voigt have provided additional insights. ${ }^{6}$ Neither, however, offers a comprehensive description. The present study aims to provide an updated analysis of the phonological integration of consonants in Greek loanwords in Syriac. In particular, the sections below provide a description of how each Greek consonantal phoneme is represented in Syriac.

This study is based on a corpus of more than eight hundred Greek loanwords and their derivatives found in pre-eighth-century Syriac texts that were not

1 For an analysis of contact-induced changes in Syriac due to Greek, see Aaron M. Butts, Language Change in the Wake of Empire: Syriac in Its Greco-Roman Context (Linguistic Studies in Ancient West Semitic, 11, Winona Lake: Eisenbrauns, 2016).

2 A useful bibliography is available in R. Voigt, 'Griechische Fremdwörter im Syrischen: Eine Bibliographie', Graeco-Arabica 7/8 (1999-200o), pp. 555-570.

3 Th. Nöldeke, Compendious Syriac Grammar. Translated from the second and improved German edition by James A. Crichton (London: Williams \& Norgate, 1904) §4B, 25, 39, 40H, 46, 51.

4 C. Brockelmann, Syrische Grammatik (Berlin: Verlag von Reuther \& Reichard, 3rd ed., 1912); T. Muraoka, Classical Syriac. A Basic Grammar with a Chrestomathy (PLO ns, 19, Wiesbaden: Harrassowitz, 2nd ed., 2005).

5 A Schall, Studien über griechische Fremdwörter im Syrischen (Darmstadt: Wissenschaftliche Buchgesellschaft, 196o) pp. 37, 42-44, 50-51, 61-62, 8o, 93, 99, 104, 107, 108, 109, 110, 111, 120, 121, 135-136, 148-150, 174, 217, 220, 232, 245.

6 S.P. Brock, 'Greek Words in Syriac: Some General Features', Scripta Classica Israelica 15 (1996), pp. 251-262 (254-257) (reprinted in his From Ephrem to Romanos. Interactions between Syriac and Greek in Late Antiquity [Aldershot: Ashgate, 1999] xv); R. Voigt, 'Das emphatische p des Syrischen', in R. Lavenant (ed.), Symposium Syriacum VII (Uppsala 1996) (ocA, 256, Rome: Pontificio Istituto Orientale, 1998) pp. 527-537. 
translated from Greek. ${ }^{7}$ This corpus has been populated from several sources: concordances to texts; ${ }^{8}$ indices to text editions that list Greek loanwords in Syriac, especially those published in the Corpus Scriptorum Christianorum Orientalium (CsCO); the readings of the present author; as well as a systematic exploitation of Michael Sokoloff's A Syriac Lexicon (2009) (= SL), which is a translation (with correction, expansion, and update) of the Lexicon Syriacum by Carl Brockelmann (1895 [1st ed.]; 1928 [2nd ed.]) (= LS2). In addition, it has been possible to search for additional occurrences of loanwords in three large 'databases': 1. the Comprehensive Aramaic Lexicon (CAL); ${ }^{9} 2$. the Oxford-BYU Syriac Corpus; ${ }^{10}$ and 3. Sebastian Brock's more than two thousand card files listing Greek loanwords in Syriac."1 These three 'databases' have been consulted on numerous occasions (though not systematically). Throughout this study, citations of Greek loanwords in Syriac are systematically provided with references to $L S 2$ and $S L$ (only rarely is a loanword not found in these lexica). The English translations in this study derive from $S L$. In several instances, it has been important to establish the earliest occurrence of a Greek loanword in Syriac. When this is the case, the earliest text attesting the loanword that is known to the present author is cited with a heading in bold giving the century of composition. Consider, for instance, the following loan-

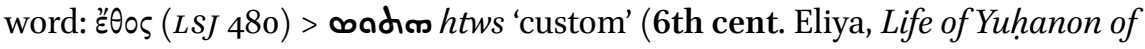
Tella, 84.26 [ed. E.W. Brooks, Vitae virorum apud Monophysitas celeberrimorum (CSCO 7-8, Louvain: Peeters, 1907), pp. 29-95]; LS2 184; SL 356). To the present author's knowledge, this word is not found in Syriac until the sixth century when it occurs in the Life of Yuhanon of Tella by Eliya, which was edited by Brooks.

$7 \quad$ The present author hopes to publish a glossary of Greek loanwords in Syriac based on this corpus at some point in the future.

For the New Testament, see G.A. Kiraz, A Computer-Generated Concordance to the Syriac New Testament (Leiden: Brill, 1993); for the Book of the Laws of the Countries, see J.A. Lund, The Book of the Laws of Countries. A Key-Word-in-Context Concordance (Piscataway, NJ: Gorgias Press, 2007); for the Book of Steps, see M. Kmosko, Liber Graduum (PS, 3, Paris: Firmin-Didot, 1907); for the Demonstrations by Aphrahat, see I. Parisot, Aphraatis Sapientis Persae Demonstrationes (PS, 1.1-2, Paris: Firmin-Didot, 1894-1907).

9 Accessible online at http://cal.huc.edu/. I am grateful to Stephen Kaufman (HUC-JIR/Cincinnati) for responding to inquiries on various occasions concerning CAL.

10 I am grateful to Kristian Heal (Brigham Young University), who generously provided me with a Beta-version of the Oxford-ByU Syriac Corpus.

11 I am grateful to Sebastian Brock (Oxford University), who allowed me to digitise his card files over several weeks in August 2011. 
It should be stressed that this study is concerned only with Greek loanwords in Syriac. It does not attempt to account for words that are closer to the Fremdwort side of the Lehnwort-Fremdwort continuum. ${ }^{12}$ The corpus does, however, err on the side of inclusion, and thus some of the words here may ultimately prove to be closer to Fremdwörter than Lehnwörter. In addition, code-switches, including single-word code-switches, have been excluded from the corpus. ${ }^{13}$ Finally, the study has not taken into account the numerous transcriptions of Greek words in Syriac, ranging from Syriac transcriptions of the Greek alphabet to the transcriptions of entire Greek passages in Syriac script. ${ }^{14}$ Thus, this study addresses only one piece of a much larger puzzle: it analyses how Greek consonants were integrated into Syriac in loanwords.

Before looking at the phonological integration of consonants in Greek loanwords in Syriac, a brief word is necessary on the Greek input form. In a vast majority of cases, Greek loanwords in Syriac reflect Attic Greek. This is perhaps unsurprising, since Attic continued to exert significant influence on the orthography of Koinē Greek. That is, the vast majority of Greek texts, especially literary texts but even documents, from Late Antiquity continue to reflect, or at least strive for, the orthography of Attic Greek, regardless of how well it reflects the actual pronunciation of the language. Occasionally, however, Greek loanwords in Syriac seem to reflect Koinē Greek input forms. In fact, positing a nonAttic input form can account for a number of cases, which prima facie seem to be irregular representations of Greek consonants in Syriac. ${ }^{15}$ Consider, for instance, the Greek loanword or 'qlysgdyqws 'expert in church

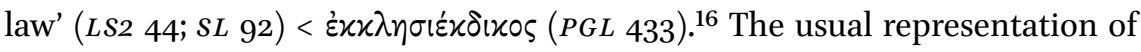
Greek $x$ is the emphatic velar stop $q$ in Syriac, as will be discussed below (see $\S 7$ ). The occurrence of Syriac $g$, which could reflect either a voiced velar stop $\mathrm{g} /$ or a voiced velar fricative $/ \mathrm{\gamma} /$, however, indicates that the Greek source may have been $\dot{\varepsilon} \varkappa \varkappa \lambda \eta \sigma \varepsilon$ ' $\gamma \delta$ ixos with the assimilation of $x$ to $\gamma$ before the voiced stop $\delta$. Interestingly, an assimilation of $\chi$ to $\gamma$ before a voiced stop is attested in Greek documents from Syria and Mesopotamia. This is reflected in writings such as the following:

12 For this continuum, see Butts, Syriac in Its Greco-Roman Context, § 4.5.

13 For code-switching in Syriac-Greek language contact, see Butts, Syriac in Its Greco-Roman Context, $\$ 4.6$.

14 For the former, see $T s$. For the latter, see S.P. Brock, 'Greek and Latin in Syriac Script', Hugoye: Journal of Syriac Studies 17 (2014), pp. 33-52.

15 For more details, see Butts, Syriac in Its Greco-Roman Context, §6.2.7.

16 For additional comments on this word, see Schall, Studien über griechische Fremdwörter im Syrischen, p. 153 . 


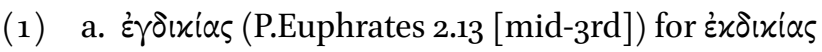

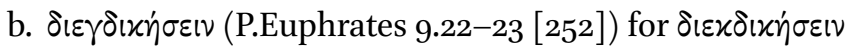

c. $\dot{\varepsilon} \gamma \beta \varepsilon \dot{\varepsilon} v \omega$ (P.Euphrates 17.22 [mid-3rd]) for $\dot{\varepsilon} x \beta \alpha i v \omega$

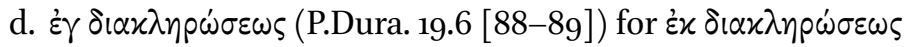

This assimilation of [+voice] is also found in Greek documents from Egypt. ${ }^{17}$ Thus, the occurrence of Syriac $g$ in

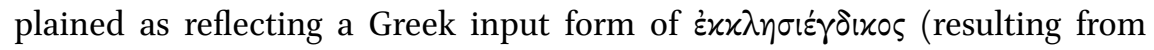
assimilation) and not as an irregular consonant correspondence for Greek $x$

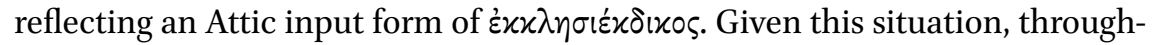
out this study, Greek forms are cited not only from Attic Greek but also at times from the Greek documents from Syria and Mesopotamia as well as from Egypt.

Greek $\beta$ was a voiced bilabial stop /b/ in Attic Greek..$^{18}$ The documentary record suggests that, at least in Egypt, it had changed into a voiced bilabial fricative $/ \beta /$ by the first century CE. ${ }^{19}$ Greek $\beta$ is typically represented in Syriac by $b,{ }^{20}$ which was realised either as a voiced bilabial stop or a voiced bilabial fricative, e.g., $\beta \hat{\eta} \mu \alpha(P G L$ 295-296; LSJ 314) > حسק bym (with alternative orthographies) 'tribunal, raised platform, bema of a Church' (LS2 68; SL 141) and $\sigma 0 \lambda \lambda \alpha \beta \eta$ ( $L S J$ 1672) > مص swlb' 'syllable' ( LS2 476; SL 979-980).

Greek $\beta$ is also represented in Syriac by $p$, which was realised either as a voiceless bilabial stop or a voiceless bilabial fricative, in xúßos (LSJ 1005)

17 F.T. Gignac, A Grammar of the Greek Papyri of the Roman and Byzantine Periods, vol. 1 (Milan: Istituto editoriale cisalpino-La goliardica, 1976) pp. 6-8o; E. Mayser, Grammatik der griechischen Papyri aus der Ptolemäerzeit, vol. 1. Laut- und Wortlehre, Part 1. Einleitung und Lautlehre (Berlin: De Gruyter, 2nd ed., 1970) pp. 143-144.

18 W.S. Allen, Vox Graeca: A Guide to the Pronunciation of Classical Greek (Cambridge: Cambridge University Press, 3rd ed., 1987) pp. 29-32; R.D. Woodard, 'Attic Greek', in R.D. Woodard (ed.), The Cambridge Encyclopedia of the World's Ancient Languages (Cambridge: Cambridge University Press, 2004) pp. 614-649 (616).

19 Gignac, A Grammar of the Greek Papyri of the Roman and Byzantine Periods, vol. 1, pp. 63, 178; Mayser, Grammatik der griechischen Papyri aus der Ptolemäerzeit, p. 145.

20 G.A. Kiraz, Tūrrāṣ Mamllā. A Grammar of the Syriac Language (Piscataway, NJ: Gorgias Press, 2012) §603-6o4; Nöldeke, Compendious Syriac Grammar, § 25; Voigt, 'Das emphatische p des Syrischen', p. $5^{28}$. 
> Taps' 'cube; piece on a draft board; tessera, mosaic tile; mosaic work; hard stone, flint' ( $L S 2685 ; S L$ 1340). This correspondence could be due to an interchange of $\beta$ and $\pi$ in the Greek source, a change that is sporadically attested in Greek documents from Egypt. ${ }^{21}$ Alternatively, the presence of $p$ could be due to the assimilation of [-voice] in Syriac: *qubsā > qup̄ss.

Greek $\beta$ is also represented in Syriac by the bilabial glide $w$ in the following words:

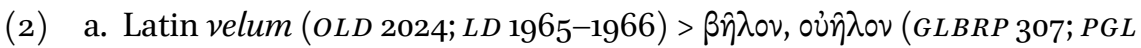
295; LSJ Suppl. 68) > لمa w'l' 'veil, curtain' (LS2 185; SL 358)

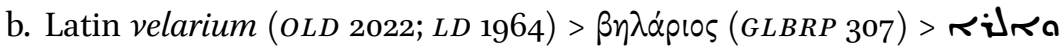
$w^{\prime} l r^{\prime}$ 'curtains' (LS2 185; SL 357)

Both of these words are ultimately of Latin origin. ${ }^{22}$ Thus, this irregular correspondence might be due to the Latin words that begin with consonantal $v$, which was probably a voiced bilabial fricative $/ \beta /$ by this time. ${ }^{23}$ These Syriac words could be direct transfers from Latin with Syriac $w$ representing Latin $v$ or the Latin may have influenced the representation in Syriac. ${ }^{24}$ It should, however, be noted that there are counter-examples in which Latin $v$ is ultimately

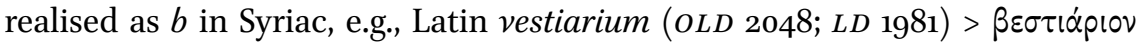

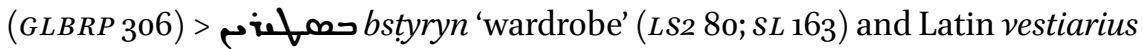

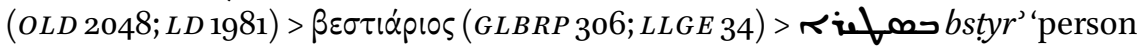
in charge of wardrobe' ( $L S 280 ; S L 163$ ), both of which only occur in the works of Yuhanonon of Ephesus (d. 581$).{ }^{25}$

21 Gignac, A Grammar of the Greek Papyri of the Roman and Byzantine Periods, vol. 1, p. 83; Mayser, Grammatik der griechischen Papyri aus der Ptolemäerzeit, p. 145.

22 For Latin loanwords in Syriac, see Aaron M. Butts, 'Latin Words in Classical Syriac', Hugoye: Journal of Syriac Studies 19 (2016). Forthcoming. For immediate versus ultimate source, see Butts, Syriac in Its Greco-Roman Context, § 4.7.

23 Gignac, A Grammar of the Greek Papyri of the Roman and Byzantine Periods, vol. 1, p. 68 with n. 2.

24 Compare also the representation of Latin personal names in Syriac, such as Valens (Syriac

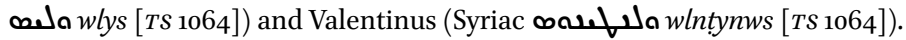

25 Again, compare the representation of Latin personal names in Syriac, such as Vestilianus

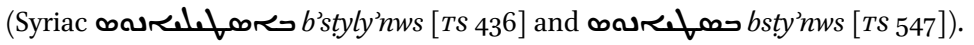




\section{$3 \quad$ Greek $\gamma$}

Greek $\gamma$ was a voiced velar stop /g/ in Attic Greek. ${ }^{26}$ During the Roman and Byzantine periods, it was in the process of becoming a voiced velar fricative $/ \gamma / .{ }^{27}$ Greek $\gamma$ is typically represented in Syriac by $g,{ }^{28}$ which was either a

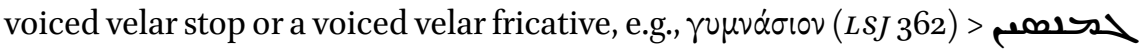
gmnsyn 'gymnasia' (LS2 121; SL 242) and $\varphi \lambda \varepsilon \dot{\gamma} \gamma \mu \alpha$ (LSJ 1943) > a plgm' 'phlegm' ( $L S 2$ 571; $S L 1195)$.

Greek $\gamma$ is also represented by the emphatic velar stop $q$ in $\pi$ úpyos (LSJ 1556) > Roمina pwrqs' 'tower' (LS2 607; $S L$ 1173). This may be the result of an assimilation of [+emphatic] due to the initial "emphatic" $p$ (for which, see $\S 12$ below). ${ }^{29}$ It should be noted that this Greek word is realised in Mandaic as parqsa $(M D 365)$, with the same correspondence, suggesting that the Mandaic is a loanword from Syriac (or less likely, that the same assimilation occurred independently in Mandaic).

Greek $\gamma$ is also represented by the voiced dental stop $d$ in $\pi$ uprioxos (LSJ

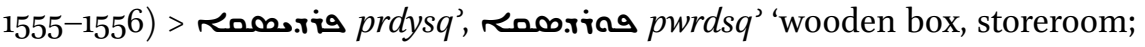
chest inserted in a wall' ( $L S 2$ 594; $S L 1228-1229$ ). Brockelmann explains this as a dissimilation of a velar to a dental in proximity to another velar. ${ }^{30}$ This is, however, ad hoc. It should be noted that the Greek word is realised in Jewish Babylonian Aramaic as prdysq ${ }^{\prime}$ (DJBA 928) and in Mandaic as pardasa (MD 363), with similar correspondences.

In the sequences $\gamma x, \gamma, \gamma \chi$, and $\gamma \mu$, Greek $\gamma$ represents the velar nasal $\eta,{ }^{31}$ which serves as an allophone of the dental nasal $\nu$ and the voiced velar stop $\gamma$.

26 Allen, Vox Graeca, pp. 29-32; Woodard, 'Attic Greek', p. 616.

27 Gignac, A Grammar of the Greek Papyri of the Roman and Byzantine Periods, vol. 1, pp. 7475, 178; Mayser, Grammatik der griechischen Papyri aus der Ptolemäerzeit, pp. 141-143.

28 Kiraz, Tūrrāṣ Mamllā, §603-604; Nöldeke, Compendious Syriac Grammar, § 25; Voigt, 'Das emphatische p des Syrischen', p. 528 .

29 Alternatively, it could be the result of an interchange of $\gamma$ and $x$ in the Greek source, a change that is attested in Greek documents from Egypt (Gignac, A Grammar of the Greek Papyri of the Roman and Byzantine Periods, vol. 1, pp. 63, 76-80; Mayser, Grammatik der griechischen Papyri aus der Ptolemäerzeit, pp. 143-144).

$30 \quad$ C. Brockelmann, Grundriß dervergleichenden Grammatik der semitischen Sprachen, Vol. I. Laut- und Formenlehre (Berlin: Reuther \& Reichard, 1908) §86d.

31 Allen, Vox Graeca, pp. 33-39; Woodard, 'Attic Greek', p. 616. The pronunciation of $\gamma$ as the velar nasal $\eta$ is sometimes reflected in spellings in Greek documents, including those

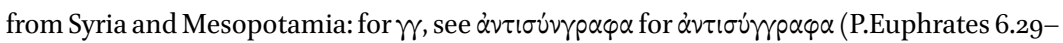

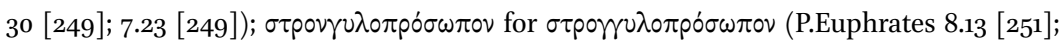

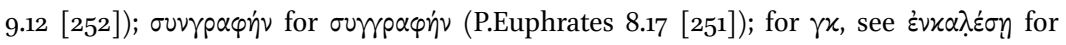


In the vast majority of cases, the Greek velar nasal is represented in Syriac with the dental nasal $n$, as in the following representative examples:

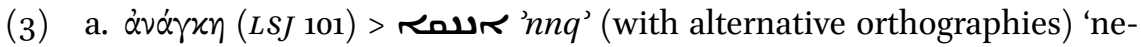
cessity' ( $L S 229 ; S L 63)$

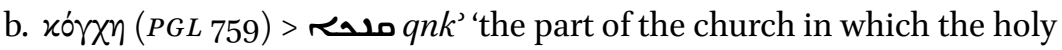
service is preformed and where the altar stands' ( $L S 2677 ; S L 1385$ )

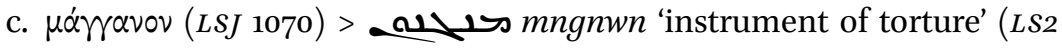
$394 ; S L 780)$

In the following cases, however, the Greek velar nasal $\eta$ is not represented in Syriac:

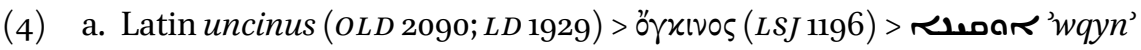
'hook; anchor; sailors' sounding line' (LS2 9; SL 20)

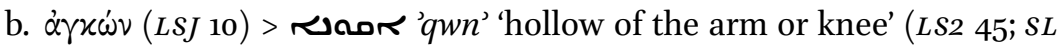
92)

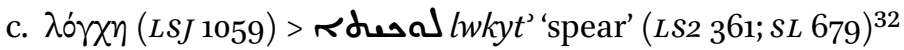

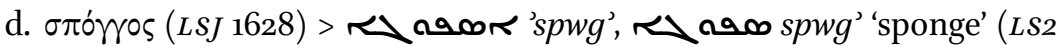
$35 ; S L 75)$

The lack of representation of the Greek velar nasal $\eta$ in these examples is due to its assimilation to a following consonant. ${ }^{33}$

\section{Greek $\delta$}

Greek $\delta$ was a voiced dental stop /d/ in Attic Greek. ${ }^{34}$ During the Roman and Byzantine periods, it was in the process of becoming a voiced dental fricative

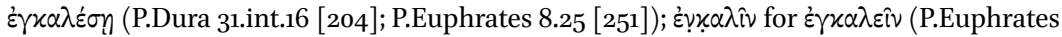

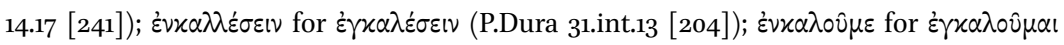
(P.Euphrates 3.12 [252-256]; 4.12; [252-256]); ह่ $v \lambda \lambda \eta \dot{\eta} \mu \alpha \tau \alpha$ for $\dot{\varepsilon} \gamma x \lambda \eta \dot{\eta} \mu \alpha \tau \alpha$ (P.Euphrates 3.11 [252-256]; 4.12 [252-256]); $\pi \dot{\alpha} v x \alpha \lambda \alpha$ for $\pi \dot{\alpha} \gamma x \alpha \lambda \alpha$ (P.Euphrates 17.9-10 [mid-3rd cent.]);

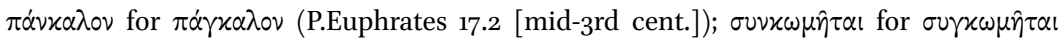

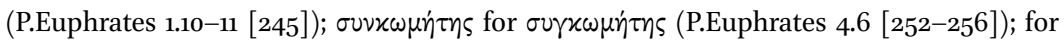

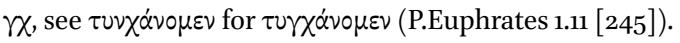

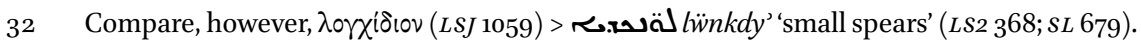

33 Alternatively (or additionally), these cases could involve nasalisation of the vowel.

34 Allen, Vox Graeca, pp. 29-32; Woodard, 'Attic Greek', p. 616. 
$/ \partial /{ }^{35}$ Greek $\delta$ is typically represented in Syriac by $d,^{36}$ which was either a voiced

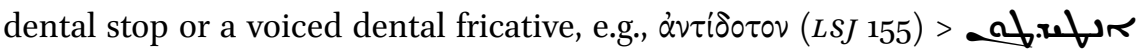

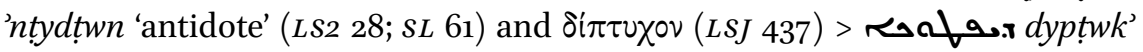
'diptych, tablet' ( $L S 2$ 162; $S L 298$ ).

Greek $\delta$ is also represented by the emphatic dental stop $t$ in $\pi \circ \delta \alpha$ r $\gamma \alpha$ (LSJ

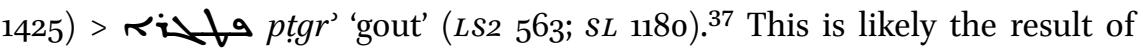
an assimilation of [+emphatic] due to the "emphatic" $p$ (for which, see $\S 12$ below). ${ }^{38}$ A similar correspondence is found in $\pi \alpha v \delta 0 x \varepsilon i 0 v(L S J$ 1296-1297) > r The Greek $\delta$ in $\pi \alpha \nu \delta 0 x \varepsilon i 0 v$ is also represented in Syriac with $t$, which was realised as either a voiceless dental stop or a voiceless dental fricative, e.g., rodia $p w t q$. This representation is more difficult to explain; perhaps, it is due to an interchange of $\delta$ and $\theta$ in the Greek source, a change that is occasionally attested in Greek documents from Egypt. ${ }^{39}$ It should be noted that these developments are not attested in other dialects of Late Aramaic in which the Greek word is found: Jewish Babylonian Aramaic puddaqo (DJBA 888), Jewish Palestinian Aramaic pwndq (DJPA 426), and Christian Palestinian Aramaic piwndq (DCPA $325-326 ; L S P$ 159). ${ }^{40}$

Greek $\delta$ is not always represented in $\pi i v a x i \delta$ iov (LSJ 1405) > R a pnqyt',

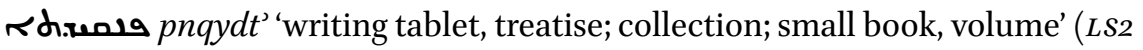
$580 ; s L 1207)$. This is due to a regressive assimilation of $d$ to $t^{41}$ It should be noted, however, that in the later vocalisation tradition $r$ seng pnqt' is

35 Gignac, A Grammar of the Greek Papyri of the Roman and Byzantine Periods, vol. 1, pp. 75 with n. 3,178 .

36 Kiraz, Türrāṣ Mamllā, §603-604; Nöldeke, Compendious Syriac Grammar, § 25; Voigt, 'Das emphatische p des Syrischen', p. $5^{28 .}$

37 The expected representation $<$ i

38 Alternatively, it could be the result of an interchange of $\delta$ and $\tau$ in the Greek source, a change that is attested in Greek documents from Egypt (Gignac, A Grammar of the Greek Papyri of the Roman and Byzantine Periods, vol. 1, pp. 63, 82-83; Mayser, Grammatik der griechischen Papyri aus der Ptolemäerzeit, pp. 146-147).

39 Gignac, A Grammar of the Greek Papyri of the Roman and Byzantine Periods, vol. 1, pp. 9697; Mayser, Grammatik der griechischen Papyri aus der Ptolemäerzeit, pp. 148-149.

40 The developments found in Syriac thus preclude it from being the immediate source of Arabic funduq- (вK 638; Lane 2449).

41 So already W. Wright, Catalogue of Syriac Manuscripts in the British Museum Acquired since the Year 1838, vol. 2 (London, 1870-1872) 633. For this sound change, see Nöldeke, Compendious Syriac Grammar, §26в and compare, e.g., *hadtā > *hadts > hatts 'new', written rdī $h(d) t^{\prime}$. 
realised as /penqiț/ with $\underline{t}(\operatorname{not} t t) .{ }^{42}$ The fricativisation of $\underline{t}$ is to be explained as secondary, likely due to an inner Syriac development whereby the Syriac ending -iț $\supset$ was used to represent the Greek ending - $1 \delta 10 v$. Finally, it should be noted that the non-assimilated spelling a pnaydt' is very rare and may well reflect a Fremdwort rather than a Lehnwort. ${ }^{43}$

In a few isolated cases, Greek $\delta$ is not represented in Syriac when it occurs in word initial position:

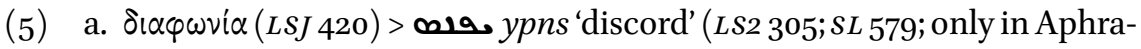
hat, Demonstrations, 605.26; 677.5 [ed. Parisot, Aphraatis Sapientis Persae Demonstrationes])

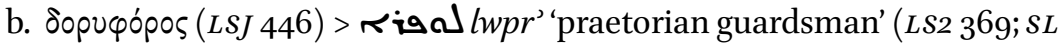
680)

If these are not simply corruptions, which seems most likely, then they could be explained as instances of meta-analysis in which the initial $d$ was misanalysed as the nominalising particle $d$-, which allowed it to be deleted from the word.

\section{$5 \quad$ Greek $\zeta$}

Greek $\zeta$ was a monograph for the consonant cluster /zd/ in Attic Greek. ${ }^{44}$ By the Koinē Greek of the Roman and Byzantine periods, it had developed into a voiced alveolar fricative $/ \mathrm{z} /{ }^{45}$ Greek $\zeta$ is always represented by the Syriac

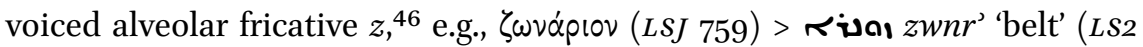

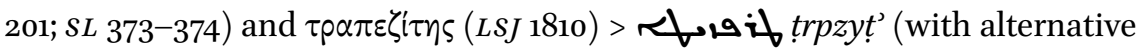
orthographies) 'money-changer' ( $L S 2291 ; S L 556)$.

42 See, e.g., Luke 1.63 in P.E. Pusey and G.H. Gwilliam, Tetraeuangelium sanctum; juxta simplicem Syrorum versionem ad fidem codicum Massorae, editionum denuo recognitum (Oxford: Clarendon Press, 1901).

43 I am grateful to an anonymous reviewer for pointing this out.

44 Allen, Vox Graeca, pp. 56-69; Woodard, 'Attic Greek', p. 616.

45 Gignac, A Grammar of the Greek Papyri of the Roman and Byzantine Periods, vol. 1, p. 120; Mayser, Grammatik der griechischen Papyri aus der Ptolemäerzeit, p. 176.

46 Kiraz, Türrāṣ Mamllā, §6o3-604. 
Greek $\theta$ was an aspirated voiceless dental stop $/ \mathrm{t}^{\mathrm{h}} /$ in Attic Greek. ${ }^{47}$ During the Roman period, it developed into a voiceless dental fricative $|\theta|,{ }^{48}$ which became the established pronunciation in the Byzantine period. Greek $\theta$ is typically represented in Syriac by $t,{ }^{49}$ which was realised as a voiceless dental

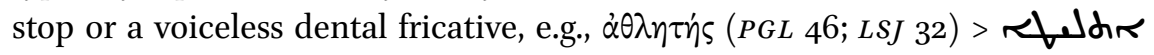

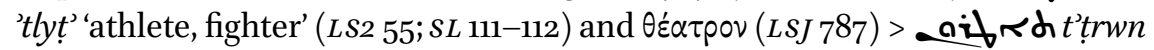
'theater; spectacle' (LS2 813; SL 1618).

Greek $\theta$ is also represented by the emphatic dental stop $t$ in $\theta$ ópußos (LSJ 803804 ) > مia twrb' 'turmoil, uproar' (LS2 287; $S L$ 521). According to Brock, this is due to analogy with $\alpha$ iq twrp 'torment' ( $L S 2291 ; S L 522) .{ }^{50}$ Alternatively, the spelling with $t$ could be due to an interchange of $\theta$ and $\tau$ in the Greek source, which is occasionally attested in Greek documents from Egypt. ${ }^{51}$

\section{$7 \quad$ Greek $x$}

Greek $x$ was a voiceless unaspirated velar stop / $\mathrm{k} /$ in Attic Greek as well as in the Koinē Greek of the Roman and Byzantine periods. ${ }^{52}$ Greek $x$ is typically

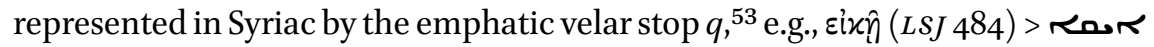

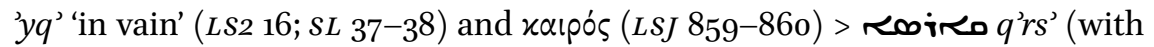

47 Allen, Vox Graeca, pp. 18-26; Woodard, 'Attic Greek', p. 616.

48 Gignac, A Grammar of the Greek Papyri of the Roman and Byzantine Periods, vol. 1, pp. 64, 178.

49 Brock, 'Greek Words in Syriac: Some General Features', p. 255; Kiraz, Tūrrāṣ Mamllā, $\S 603-604$; Nöldeke, Compendious Syriac Grammar, §25; Voigt, 'Das emphatische p des Syrischen', p. $5^{28 .}$

5o S.P. Brock, 'Greek Words in the Syriac Gospels (vet and pe)', Le Muséon 80 (1967), pp. 389426 (402).

$51 \quad$ Gignac, A Grammar of the Greek Papyri of the Roman and Byzantine Periods, vol. 1, pp. 8696, esp. 91 (word initial); Mayser, Grammatik der griechischen Papyri aus der Ptolemäerzeit, pp. 147-148.

52 For Attic, see Allen, Vox Graeca, pp. 17-18; Woodard, 'Attic Greek', p. 616. For Koinē, see Gignac, A Grammar of the Greek Papyri of the Roman and Byzantine Periods, vol. 1, pp. 63, 178.

53 Brock, 'Greek Words in Syriac: Some General Features', p. 255; Kiraz, Tūrrāṣ Mamllā, $\S 603^{-604}$; Schall, Studien über griechische Fremdwörter im Syrischen, p. 37; Voigt, 'Das emphatische p des Syrischen', p. $5^{28 .}$ 
alternative orthographies) 'time; mischance; distress, difficulty; war' (LS2 698; $S L$ 1308).

In a few isolated cases, Greek $x$ is represented by the voiced velar stop $g:{ }^{54}$

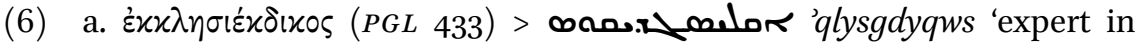
church law' (LS2 44; SL 92)

b. $x \alpha \lambda \lambda i \alpha \varsigma(L S J 867)>$ ald $g l s$ 'ape, monkey' (LS2 118; SL 238)

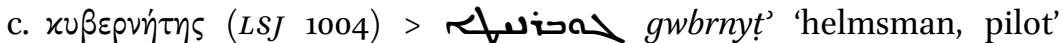
(LS2 103; SL 210; only in Aphrahat, Demonstrations, 1.612.2 [ed. Parisot, Aphraatis Sapientis Persae Demonstrationes]), though usually

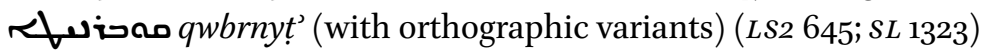

As discussed above in $\S 1$, this representation is to be explained by an interchange of $\gamma$ for $x$ in the Greek source, which is encountered in Greek documents from Egypt as well as from Syria and Mesopotamia. It should be noted that for at least one of the words in (6) the Greek form with $\gamma$ is actually attested in a

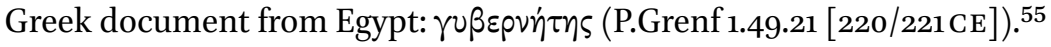

Greek $x$ is represented in Syriac by $k$, which was realised as a voiceless velar stop or a voiceless velar fricative, in the following isolated cases: ${ }^{56}$

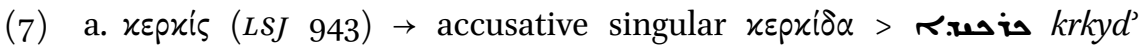
'weaver's come' (LS2 346; SL 654-655)

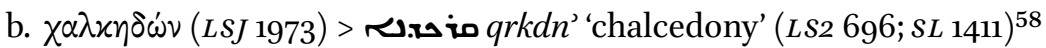

The seeming irregular correspondence found in these words is likely due to an interchange of $x$ and $\chi$ in the presence of a liquid in the Greek source, a change that is sporadically attested in Greek documents from Egypt. ${ }^{59} \mathrm{~A}$ third

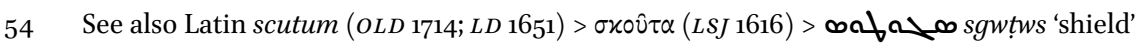
(LS2 459; SL 967).

55 The change from voiceless to voiced velar stop is also reflected in Latin gubernare ( $L D 831)$, which is a loanword from Greek.

$5^{6}$ See Schall, Studien über griechische Fremdwörter im Syrischen, pp. 37, 220.

57 This representation is also found in Jewish Palestinian Aramaic $k r k d$ 'staff used for beating' (DJPA 269-270).

$5^{8}$ This would not be the only irregular consonant correspondence in the word: $\chi=\operatorname{Syriac} q$, but usually $k$ (see $\S 17$ ); $\lambda$ = Syriac $r$, but usually $l$ (see $\S 8$ ). The phonology is a better fit for xapXnóovios 'Carthaginian' (LSJ 881) or the like.

59 Gignac, A Grammar of the Greek Papyri of the Roman and Byzantine Periods, vol. 1, pp. 899o; Mayser, Grammatik der griechischen Papyri aus der Ptolemäerzeit, pp. 144-145. 
case of this representation could potentially be found in rase pynk' 'dish, writing tablet' ( $L S 2579 ; S L 1188$ ), if the input form is $\pi i v \alpha \alpha \alpha$, the accusative of $\pi i v \alpha \xi$ (LSJ 1405). It is, however, preferable to follow Brock in taking the input form to be the nominative $\pi i v \alpha \xi$ in which case Greek $\xi$ would be realised as Syriac $k s$, as is typical (see $\S 11$ below), followed by the loss of the case marker $-s$, leaving only k. ${ }^{60}$ If Brock's proposal is accepted, then Syriac rale pynk' is not an additional example of the correspondence of Greek $x$ with Syriac $k$.

In the Ecclesiastical History by Pseudo-Zacharias (6th cent.), Greek $x$ is represented by the emphatic dental stop $t$ in $\gamma \lambda \omega \sigma \sigma o ́ x o \mu o v(L S J 353)>2$ ( glwstm' 'chest, box, case' (LS2 119; SL 233-234). ${ }^{61}$ This representation is difficult to explain. The fact that a similar spelling occurs in Mandaic glușțuma, glușțma (MD 1963) suggests that the Mandaic is a loanword from Syriac.

Greek $\lambda$ was an alveolar lateral approximant /l/ in Attic Greek as well as in the Koinē Greek of the Roman and Byzantine periods. ${ }^{62}$ It is typically represented

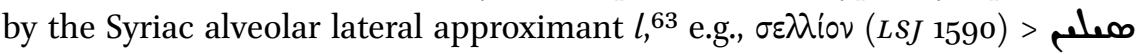
sylyn 'small chair; latrine, toilet' ( $L S 2476 ; S L$ 149; 1001) and Ǔ $\lambda \eta$ ( $L S J$ 1847-1848) $>$ 『nos $h w l$ ' (with alternative orthographies) 'woods, forest; matter, material; firewood' ( $L S 2$ 173, 175; SL 335, 341).

Greek $\lambda$ may be represented by the alveolar trill $r$ in two words, though both are quite uncertain:

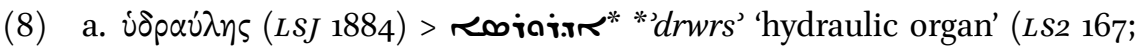
$S L$ 11) only possibly in Acts of Thomas, 279.8 (ed. W. Wright, Apocryphal

6o Brock, 'Greek Words in the Syriac Gospels (vet and pe)', p. 413. For the integration of Greek case endings in Syriac, see Butts, Syriac in Its Greco-Roman Context, § 6.2.3.

61 See also Th. Nöldeke, Mandäische Grammatik (Halle: Buchhandlung des Waisenhauses, 1875) p. xxx; Brock, 'Greek Words in the Syriac Gospels (vet and pe)', p. 397. The usual spelling in Syriac is of [+emphatic] is also attested. Compare also Christian Palestinian Aramaic gwlwsqwmwn 'bag, purse' (DCPA 73; LSP 38) and Jewish Palestinian Aramaic glwsqwm (DJPA 129). The Ecclesiastical History by Pseudo-Zacharias is edited in E.W. Brooks, Historia ecclesiastica Zachariae Rhetori vulgo adscripta, 1-2 (csco, 83-84, 87-88, Louvain: Peeters, 1919-1924).

62 For Attic, see Allen, Vox Graeca, pp. 39-40; Woodard, 'Attic Greek', p. 616; for Koinē, see Gignac, A Grammar of the Greek Papyri of the Roman and Byzantine Periods, vol. 1, p. 178.

63 Kiraz, Türrāṣ Mamllā, §6o3-604. 
Acts of the Apostles [London: Williams and Norgate, 1871]), which

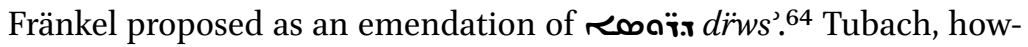
ever, has argued that this emendation is unnecessary, proposing in-

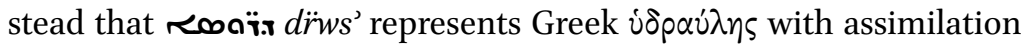

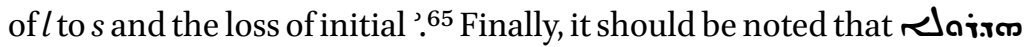
$h d r w l^{\prime}(L S 2172 ; S L 332)$ is the more common form of the word.

b. $\chi \alpha \lambda \times \eta \delta$ ' $\omega v$ (LSJ 1973) > من $q r k d n$ ' 'chalcedony' (LS2 696; SL 1411). This would not be the only irregular consonant correspondence in the word (see fn. $5^{8}$ above).

If these examples are admitted, they could be explained by an interchange of $\rho$ and $\lambda$ in the Greek source, a change that is attested in Greek documents from Egypt. ${ }^{66}$

Greek $\lambda$ is not consistently represented in $\beta \alpha \lambda \alpha v \varepsilon i ̂ 0$ (LSJ 303) > حص bn' 'bath' ( $L S 278 ; S L 161$ ) due to haplography. ${ }^{67}$ This haplography is also found in Jewish Palestinian Aramaic bny (DJPA 105) and Jewish Babylonian Aramaic banne, b'ny (DJBA 209). The form without haplography is, however, attested in Syriac bln' 'bath' (LS2 76; SL 158) as well as in Jewish Palestinian Aramaic blny (DJPA 104).

An irregular representation of Greek $\lambda$ with Syriac $n$ is found in $\lambda \alpha \mu \pi \tau \dot{p} p$ (LSJ 1028) > Riva nptyr' 'lantern, torch' (LS2 436; $S L$ 930). This representation might possibly be explained by a change of $\lambda$ to $\nu$ in the Greek source, which is rarely attested in Greek documents from Egypt. ${ }^{68}$

The interchanges of $l, n$, and/or $r$ in the previously discussed words could also be explained as (irregular) internal changes in Syriac, especially since these three sounds share a number of features.

64 S. Fränkel, 'Beiträge zum syrischen Wörterbuche', zA 17 (1903), pp. 85-9o (86). Wright (Apocryphal Acts of the Apostles, p. 279), Fränkel ('Beiträge zum syrischen Wörterbuche', p. 86), Brockelmann (LS2 167), Schall (Studien über griechische Fremdwörter im Syrischen, p. 120), and Tubach ('Zur Interpretation des Perlenliedes. Exegetische Prämissen und ihre Schlussfolgerungen', in D. Bumazhnov and H.R. Seeliger [eds.], Syrien im 1.-7. Jahrhundert nach Christus. Akten des 1. Tübinger Tagung zum Christlichen Orient [15.-16. Juni 2007]

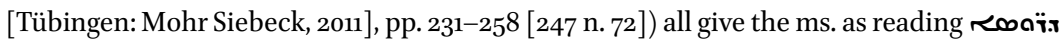

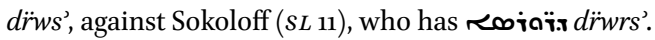

65 Tubach, 'Zur Interpretation des Perlenliedes', p. 247 n. 72.

66 Gignac, A Grammar of the Greek Papyri of the Roman and Byzantine Periods, vol. 1, pp. 102107; Mayser, Grammatik der griechischen Papyri aus der Ptolemäerzeit, pp. 161-162.

67 Brockelmann, Grundriß der vergleichenden Grammatik der semitischen Sprachen, § 97 $2 \alpha$; Schall, Studien über griechische Fremdwörter im Syrischen, pp. 61-62.

68 Gignac, A Grammar of the Greek Papyri of the Roman and Byzantine Periods, vol. 1, pp. 109110. 


\section{$9 \quad$ Greek $\mu$}

Greek $\mu$ was a bilabial nasal $/ \mathrm{m} /$ in Attic Greek as well as in the Koinē Greek of the Roman and Byzantine periods. ${ }^{69}$ It is typically represented by the Syr-

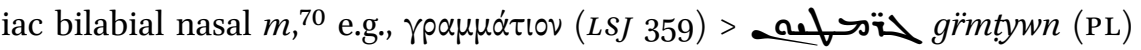
'promissory note' (LS2 133, 841; SL 261) and $\mu \dot{\varepsilon} v(L S J$ 1101-1102) > ה $m n$ 'indeed' (LS2 393; SL 778).

In the following isolated cases, Greek $\mu$ is not represented in Syriac: ${ }^{71}$

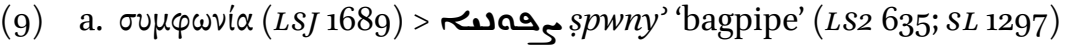

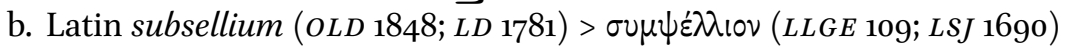
$>$ Nanasl' 'bench' (LS2 455, 491; $S L$ 963, 1032), also attested as Nosbsl', which likely represents the Latin

These examples are to be explained as a loss of the bilabial nasal $\mu$ before a labial stop in the Greek source, a change that is attested in Greek documents from Egypt. ${ }^{72}$

Greek $\mu$ is represented by Syriac $n$ in $\sigma u ́ \mu \pi$ ovos (LSJ 1685; PGL 1289) > ariaros swnpnws 'supervisor of the trades people of Constantinople on behalf of the eparch of the city' ( $L S 2485 ; S L 984$ ). This is due to a dissimilation of $\mu$ to $\nu$ before a labial in the Greek source, a change which is encountered in Greek documents from Egypt as well as from Syria and Mesopotamia. ${ }^{73}$

69 For Attic, see Allen, Vox Graeca, p. 33; Woodard, 'Attic Greek', p. 616; for Koinē, see Gignac, A Grammar of the Greek Papyri of the Roman and Byzantine Periods, vol. 1, p. 178.

70 Kiraz, Türrās Mamllā, §603-604.

71 See also $\lambda \alpha \mu \pi \tau \dot{p} \rho(L S J$ 1028) > Ri் attests the irregular correspondence of Greek $\lambda$ with Syriac $n$ (see $\S 8$ above).

72 Gignac, A Grammar of the Greek Papyri of the Roman and Byzantine Periods, vol. 1, p. 117; Mayser, Grammatik der griechischen Papyri aus der Ptolemäerzeit, p. 165.

73 For Egypt, see Gignac, A Grammar of the Greek Papyri of the Roman and Byzantine Periods, vol. 1, pp. 167-169; Mayser, Grammatik der griechischen Papyri aus der Ptolemäerzeit,

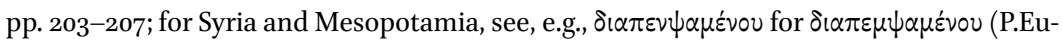

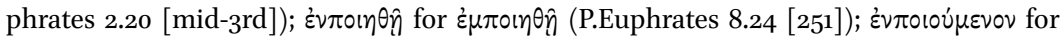

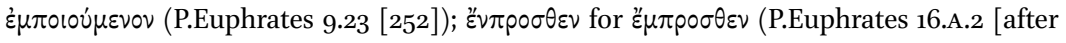

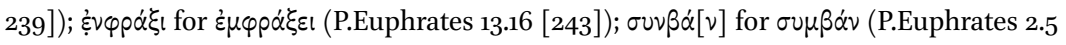

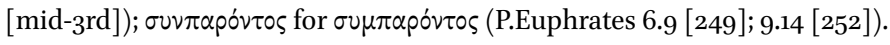


Greek $v$ was an alveolar nasal /n/ in Attic Greek as well as in the Koinē Greek of the Roman and Byzantine periods. ${ }^{74}$ It is typically represented by the Syriac

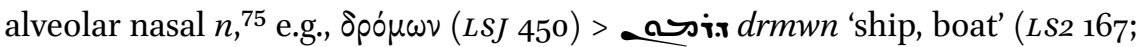

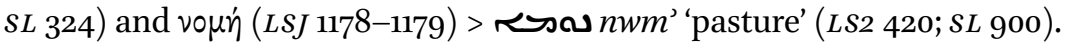

In rare cases, Greek $v$ is not represented in Syriac: ${ }^{76}$

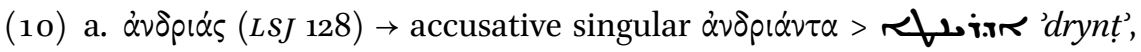

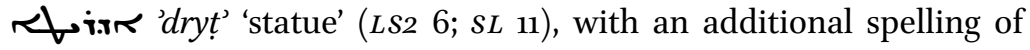

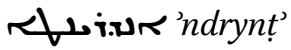

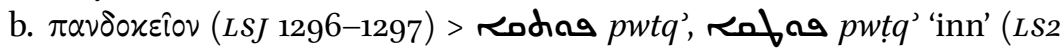
$565,618 ; S L 1162,1177)$

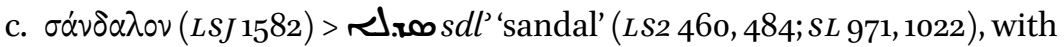
an additional spelling of ${ }^{2}$ sndl'

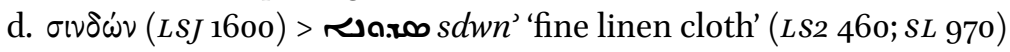

This is either due to an assimilation of $\nu$ to a following dental in the Greek source, a change that is attested in Greek documents from Egypt, ${ }^{77}$ or to an inner Syriac development whereby $n$ assimilates to a following consonant. Given the regularity of the latter, it seems more likely.

Initial $v$ is irregularly deleted in veavioxos (LSJ 1164) > حمم ynsq' 'youth' (LS2 304; SL 577), which also occurs as صلصمم nynsq' (LS2 427; SL 915).

11

\section{Greek $\xi$}

Greek $\xi$ is a monograph for the voiceless unaspirated velar stop $x$ and the voiceless alveolar fricative $\sigma$ in Attic Greek as well as in the Koinē Greek of the

74 For Attic, see Allen, Vox Graeca, pp. 33-39; Woodard, 'Attic Greek', 616; for Koinē, see Gignac, A Grammar of the Greek Papyri of the Roman and Byzantine Periods, vol. 1, p. 178.

75 Kiraz, Tūrrāṣ Mamllā, §603-604.

76 See also Latin mansio (OLD 1074; $L D$ 1109) > Parasants' ( $L S 2396 ; S L 790$ ). It should be noted that Latin $n s$ is normally realised simply as $\sigma$ in Latin loanwords in Greek (Gignac, A Grammar of the Greek Papyri of the Roman and Byzantine Periods, vol. 1, pp. 117-118).

77 Gignac, A Grammar of the Greek Papyri of the Roman and Byzantine Periods, vol. 1, p. 116; L.R. Palmer, A Grammar of the Post-Ptolemaic Papyri (London: Oxford University Press, 1945) p. 2. This change in Greek may additionally involve nasalisation of the vowel. 
Roman and Byzantine periods. ${ }^{78}$ Greek $\xi$ is typically represented in Syriac by two consonants: $k$, which was realised as a voiceless velar stop or a voiceless velar fricative, and the voiceless alveolar fricative $s^{79}$ e.g., Latin $d u x$ ( $O L D 582$;

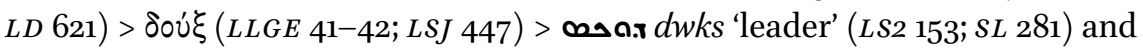

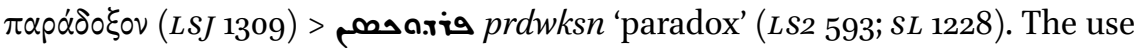
of $k$, instead of the emphatic velar stop $q$, suggests that the initial segment of Greek $\xi$ was at least partially aspirated, i.e., $/ \mathrm{k}^{\mathrm{h}} \mathrm{s} /$, a realisation that is supported by other evidence..$^{80}$

Greek $\xi$ is represented by the emphatic velar stop $q$ and the voiceless alveolar

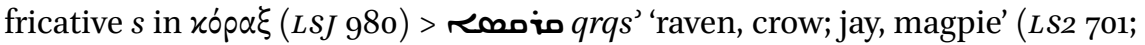
$S L$ 1416). This representation corresponds to the expected representation of a monograph for the voiceless unaspirated velar stop $x$ and the voiceless alveolar fricative $\sigma$.

In a few rare cases, Greek $\xi$ is represented by $s$, without $k$ :

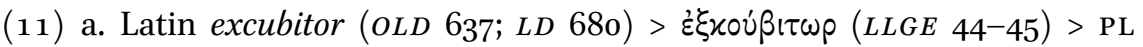

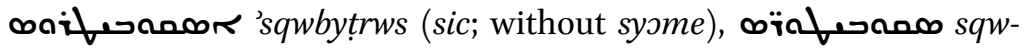

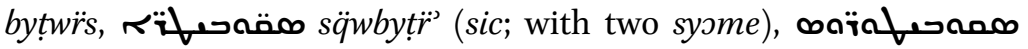
sqwbytwrïws 'excubitores, Byzantine palace guards' (LS2 493; SL 1037)

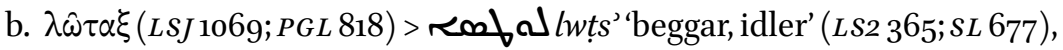

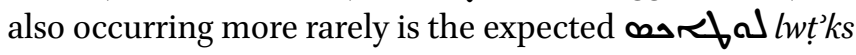

There are no sound changes in Greek or Syriac that can account for this representation. Perhaps the former is due to the complex initial syllable cluster whereas the latter represents the triradicalisation of a Greek loanword.

Greek $\xi$ is irregularly represented by the emphatic velar stop $q$, without the

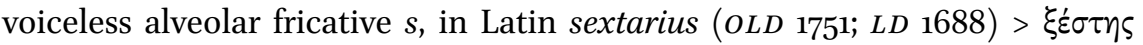

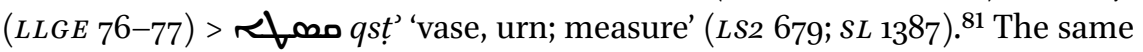
correspondence is found already in Palmyrene qsțn (PAT 406) as well as

78 For Attic, see Allen, Vox Graeca, pp. 59-6o; Woodard, 'Attic Greek', p. 616; for Koinē, see Gignac, A Grammar of the Greek Papyri of the Roman and Byzantine Periods, vol. 1, pp. 139141; Mayser, Grammatik der griechischen Papyri aus der Ptolemäerzeit, pp. 184-185.

79 Brock, 'Greek Words in Syriac: Some General Features', p. 255; Kiraz, Tūrrāṣ Mamllā, §12, 603-604; Nöldeke, Compendious Syriac Grammar, §25; Voigt, 'Das emphatische p des Syrischen', pp. 529-531.

80 See T. Harviainen, 'On the Loss of the Greek /h/ and the So-called Aspirated Rhō', Studia Orientalia 45 (1976), pp. 1-88 (20 with the references in n. 3).

81 Brock, 'Some Aspects of Greek Words in Syriac', p. 83 n. 20; Voigt, 'Das emphatische p des Syrischen', p. 530. Various Greek sources have been proposed, for which, see PAT 1018. 
in Jewish Palestinian Aramaic qsyt (DJPA 498), Christian Palestinian Aramaic qyst (DCPA 372; LSP 181), and Jewish Babylonian Aramaic qisț, qyst' (DJBA 1014). This representation is difficult to account for, but it may be due to the triradicalisation of a Greek loanword.

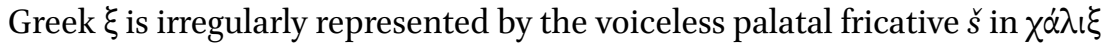
'gravel' (LSJ 1972) > א kls 'lime' (LS2 330; SL 627). ${ }^{82}$

Greek $\pi$ was a voiceless unaspirated bilabial stop /p/ in Attic Greek as well as in the Koinē Greek of the Roman and Byzantine periods. ${ }^{83}$ It is typically represented in Syriac by $p,{ }^{84}$ which was realised either as a voiced bilabial stop or a voiceless bilabial fricative in native Syriac words, e.g., $\delta i \pi \tau v \chi 0 v(L S J 437)>$

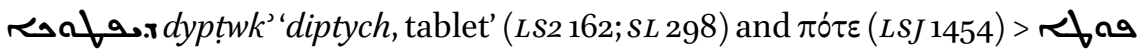
$p w t^{\prime}$ 'ever' (LS2 559; SL 1162).

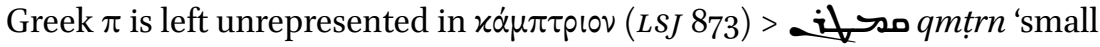
chest' ( $L S 2672 ; S L$ 1377). This reflects the deletion of $\pi$ in the cluster $\mu \pi \tau$ in the Greek source, a change that is well attested in Greek documents from Egypt. ${ }^{85}$

Syriac $p$ was realised as a voiced bilabial stop /p/ or a voiceless bilabial fricative $/ \overline{\mathrm{p}} /(=\mathrm{IPA} / \phi /)$ in native Syriac words. There is, however, evidence that suggests that Syriac $p$, when representing Greek $\pi$, was an emphatic bilabial stop. The clearest support for this from the period that is of interest to this study derives from cases of the assimilation of the feature [+emphatic] due to the presence of this "emphatic" $p(<$ Greek $\pi$ ), as is illustrated in the following words: 86

(12) a. $\pi 0 \delta \alpha \gamma \gamma p \alpha(L S J 1425)>$ Riخ the expected representation $R$ i

82 See also Schall, Studien über griechische Fremdwörter im Syrischen, p. 111.

83 For Attic, see Allen, Vox Graeca, pp. 14-16; Woodard, 'Attic Greek', p. 616; for Koinē, see Gignac, A Grammar of the Greek Papyri of the Roman and Byzantine Periods, vol. 1, p. 178.

84 Brock, 'Greek Words in Syriac: Some General Features', p. 255; Kiraz, Tūrrāṣ Mamllā, §603-604; Nöldeke, Compendious Syriac Grammar, § 25; R. Voigt, 'Das emphatische p des Syrischen'.

85 Gignac, A Grammar of the Greek Papyri of the Roman and Byzantine Periods, vol. 1, p. 64; Mayser, Grammatik der griechischen Papyri aus der Ptolemäerzeit, p. 152.

86 Brock, 'Greek Words in the Syriac Gospels (vet and pe)', p. 420; Schall, Studien über griechische Fremdwörter im Syrischen, p. 8o; Voigt, 'Das emphatische p des Syrischen', pp. 531-532. 


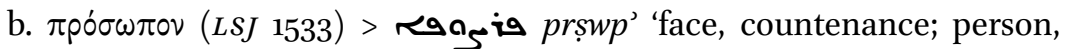

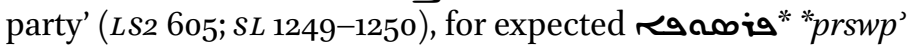

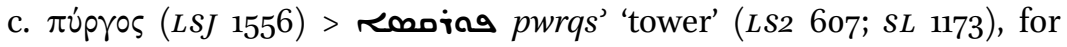
expected ron ina * "pwrgs"

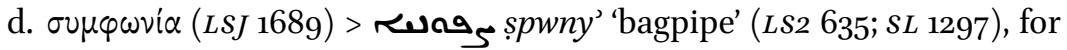
expected (Dan. 3:5, 15), sypnyh (Dan. 3:10 [k]), supponys (Dan. 3:10 [q]) (HALOT 1937-1938) without emphatic $s$

In each of these cases, the presence of an "emphatic" $p(<$ Greek $\pi$ ) led to the assimilation of a stop (whether voiced or voiceless) to its emphatic counterpart. An additional assimilation of [+emphatic] occurs systematically in the cT-stem of $\pi \varepsilon \hat{\imath} \sigma \alpha \mathrm{l}$ (LSJ 1353-1354) > rt. ल a pys C 'to persuade, to convince; to demand, seek, beseech' (LS2 567; SL 1188), which is usually written mafdr 'ttpys. ${ }^{87}$

In the later Syriac vocalisation traditions, the "emphatic" $p$ is marked with the same diacritic point that is used to distinguish the non-emphatic voiceless stops from their fricative counterparts. ${ }^{88}$ In his grammatical works, Bar Ebroyo

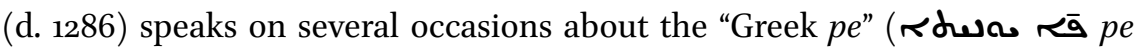
yawnsyts) that is found in $\boldsymbol{\Omega a n}_{5}$ in prșwp' 'face, countenance; person, party'

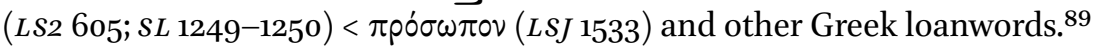

An "emphatic" $p$ also occurs with Greek loanwords in Christian Palestinian Aramaic, ${ }^{90}$ e.g., $\dot{\alpha} \sigma \pi i \varsigma$ ( LSJ 259) > 'spys 'snake' (DCPA 23; LSP 15). In the Christian Palestinian Aramaic script, this "emphatic" $p$ can be written either with the sign of the voiceless bilabial stop $(\boldsymbol{\Theta})$ or with a reversed form of this sign $(\boldsymbol{e})$. The "emphatic" $p$ in Syriac and Christian Palestinian Aramaic can be compared to the Classical Ethiopic (Gə`əz) characters that are usually transcribed as $p$ $(\boldsymbol{T})$ and $\dot{p}(\mathbf{k}) .{ }^{91}$ These characters occur almost exclusively in loanwords of

87 See already Schall, Studien über griechische Fremdwörter im Syrischen, p. 80.

88 Kiraz, Tūrrāṣ Mamllā, §214; cf. §63, 68; Nöldeke, Compendious Syriac Grammar, §15; J.B. Segal, The Diacritical Point and the Accents in Syriac (London Oriental Series, 2, London: Oxford University Press, 1953) 488. In the later West-Syriac tradition, this point is placed in the middle of $p$ thereby differentiating it from both the voiceless bilabial stop and the voiceless bilabial fricative (Kiraz, Türrāṣ Mamllā, § 214).

89 See Voigt, 'Das emphatische p des Syrischen', pp. 532-536 with additional references.

9o Ch. Müller-Kessler, Grammatik des Christlich-Palästinisch-Aramäischen (Hildesheim: G. Olms, 1991), § 2.1.2.4.

91 It should be noted that the Classical Ethiopic reflex of the Proto-Semitic voiceless bilabial stop $*$ is /f/. 
various origins, including from Greek, ${ }^{92}$ e.g., $\pi v \varepsilon \hat{\mu} \mu \alpha$ 'spirit' (LSJ 1424) > penəmu 'Satan' (CDG 413) and $\pi \dot{\lambda} \lambda ı \varsigma$ 'city' ( $L S J$ 1433-1434) > polis 'capital city' (CDG 414). Christian Palestinian Aramaic, Syriac, and Classical Ethiopic each underwent a prolonged period of contact with Greek that resulted in, inter alia, the presence of a number of Greek loanwords in these languages. Each of these languages dealt in similar but distinct ways with Greek $\pi$ : Classical Ethiopic went the furthest in innovating two characters to represent the foreign sound; Christian Palestinian Aramaic used an existing character, both in its normal form and in an inverted form; and Syriac used an existing character, which in the later tradition was marked with a diacritical point.

Since there is no independent sign for the "emphatic" $p$ in the Syriac script and since Syriac $p$ also represents Greek $\varphi$ (see $\S 16$ below), a few homographs result:93

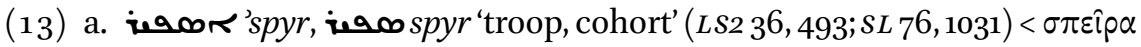
(LSJ 1625) vs. Rivaor 'spyr', Riva spyr', inaمr 'spyr 'sphere; circle; ball; pine cone; cake' (LS2 36, 493; $S L 76,1031)<\sigma \varphi \alpha i p \alpha(L S J 1738)$

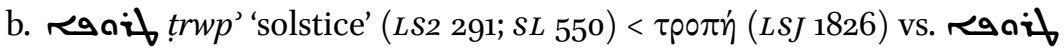

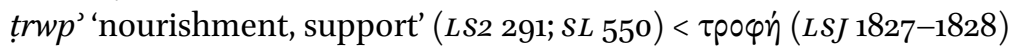

This homography is limited to the bilabial triad since the emphatic members of the dental and velar triads have an independent sign in the Syriac consonantal script.

13

\section{Greek $\rho$}

Greek $\rho$ was a voiced alveolar trill / $/ \mathrm{in}$ ittic Greek as well as in the Koinē Greek of the Roman and Byzantine periods. ${ }^{94}$ In Attic Greek, a voiceless allophonic realisation, i.e., $/ \mathrm{r} /$, also occurred when in word initial position or when geminated. ${ }^{95}$ This allophone was lost during the Roman period. ${ }^{96}$ When not clause

92 G. Gragg, 'Ge'ez (Aksum)', in Woodard, The Cambridge Encyclopedia of the World's Ancient Languages, pp. 427-453 (435); J. Tropper, Altäthiopisch: Grammatik des Ge'ez mit Übungstexten und Glossar (ELO 2, Münster: Ugarit-Verlag, 2002) § 31.1.

93 Brock, 'Greek Words in Syriac: Some General Features', p. 255.

94 For Attic, see Allen, Vox Graeca, pp. 39-45; Woodard, 'Attic Greek', p. 616; for Koinē, see Gignac, A Grammar of the Greek Papyri of the Roman and Byzantine Periods, vol. 1, p. 178. Allen, Vox Graeca, pp. 41-45.

96 For discussion, see Harviainen, 'On the Loss of the Greek /h/ and the So-called Aspirated Rhō'. 
initial and not geminated, Greek $\rho$ is typically represented in Syriac by the

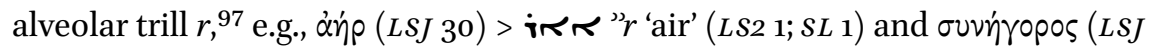
$1715)>~ R i v 10$ sngr' (with alternative orthographies) 'advocate' (LS2 483; $S L$ 1022).

Greek $\rho$ is represented by the voiced alveolar lateral approximant $l$ in $\delta$ opu-

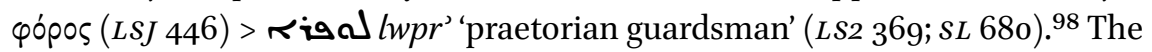
representation of Greek $\rho$ with Syriac / may be due to a dissimilation of $\rho$ preceding another $\rho$ in the Greek source, a change that is attested in Greek documents from Egypt. ${ }^{99}$ It should be noted, however, that there is an additional irregularity in this case with the loss of the initial syllable $\delta 0$ - (see $\S 4$ above).

Greek $\rho$ is represented by the alveolar nasal $n$ in uaprapitns (LSJ 1080) $>$ Rdw is mrgnyt' 'pearl; Eucharistic wafer' (LS2 402; $S L$ 826). ${ }^{100}$ This is traditionally said to be due to a dissimilation of $r$ to $n$ following another $r$ in Syriac. ${ }^{101}$ It should be noted, however, that this dissimilation is mostly, if not entirely, limited to loanwords in Syriac.

When word initial, Greek $p$ occurs with spiritus asper and was realised as a voiceless alveolar trill $/ \mathrm{r} /$ in Attic Greek. ${ }^{102}$ During the Roman period, the allophonic realisation was lost and initial Greek $\rho$ was a voiced alveolar trill $/ \mathrm{r} / .{ }^{103}$ Greek $\rho$ can be represented either with $r h$ or $r$ in Syriac. In loanwords that are first attested in Syriac by the fifth century, initial Greek $\dot{\rho}$ with spiritus asper is represented in Syriac with $r h:{ }^{104}$

97 Kiraz, Tūrrāṣ Mamllā, §603-604.

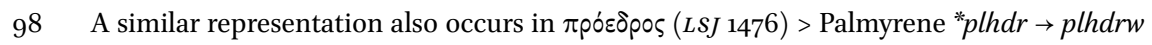
'presidency' (PAT 40o; see also S.P. Brock, 'Greek and Latin Words in Palmyrene Inscriptions: A Comparison with Syriac', in E. Cussini [ed.], AJourney to Palmyra: Collected Essays to Remember Delbert R. Hillers [Leiden: Brill, 2005] pp. 11-25 [20, 24]).

99 Gignac, A Grammar of the Greek Papyri of the Roman and Byzantine Periods, vol. 1, pp. 103104; Mayser, Grammatik der griechischen Papyri aus der Ptolemäerzeit, p. 161. Harviainen ('On the Loss of the Greek /h/ and the So-called Aspirated Rhō', p. 19) argues that the Palmyrene form in the previous footnote is due to a dissimilation in Semitic; the sound change is, however, better attested in Greek.

100 For the related Iranian forms, see C.A. Ciancaglini, Iranian Loanwords in Syriac (Wiesbaden: Harrassowitz, 2008) p. 207.

101 See, e.g., Brockelmann, Syrische Grammatik, p. 35; Ciancaglini, Iranian Loanwords in Syriac, p. 78.

102 Allen, Vox Graeca, pp. 41-42.

103 Harviainen, 'On the Loss of the Greek /h/ and the So-called Aspirated Rhō'.

104 Brock, 'Greek Words in Syriac: Some General Features', p. 256; Harviainen, 'On the Loss of the Greek /h/ and the So-called Aspirated Rhō', p. 66; Nöldeke, Compendious Syriac Grammar, §39; Schall, Studien über griechische Fremdwörter im Syrischen, p. 99. See also 


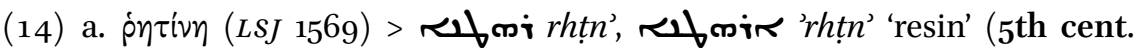
Julian Romance, 51.12 [ed. Hoffmann, Iulianos der Abtruennige], already in Gen 37.25; 43.11; LS2 727; SL 1460) ${ }^{105}$

b. ṕnं (4th cent. Ephrem, Prose Refutations, Discourse 1, 58.21 [ed. J.J. Overbeck, S. Ephraemi Syri Rabulae episcopi Edesseni Balaei aliorumque Opera selecta (Oxford: Clarendon Press, 1865), 21-58]; LS2 727; SL 1442)

This representation reflects the older pronunciation. ${ }^{106}$ In loanwords that are not attested until after the fifth century, however, initial Greek $\dot{\rho}$ with spiritus asper can be represented simply with $r$ in Syriac, ${ }^{107}$ e.g., pora (PGL 1217) > ح 2 i $r w g$ ' 'pay, wages; paying of wages' (6th cent. Yuhanon of Ephesus, Ecclesiastical History, Part 3, 129.26; 270.26 [ed. E.W. Brooks, Iohannis Ephesini. Historiae Ecclesiasticae. Pars Tertia (csCO 105, Louvain: Peeters, 1935)]; LS2 711; $S L$ 1443). The representation with $r$ (without $h$ ) reflects the loss of the allophonic realisation of word-initial $\rho$ in the Greek source.

As in the case of word-initial $\rho$, geminated Greek $p \rho$ (written $\rho \hat{\rho}$ in Byzantine orthography) was realised as a voiceless alveolar trill $/ \mathrm{r} /$ in Attic Greek. ${ }^{108}$ The allophonic realisation was lost in the Roman period. Harviainen dates this change to the fourth century. ${ }^{109}$ Medial $\hat{\rho} \rho$ is represented in Syriac by the alveolar trill $r$ with a following voiceless glottal fricative $h$ in $\alpha \dot{p} \rho \alpha \beta \omega \dot{~(L S J ~}$

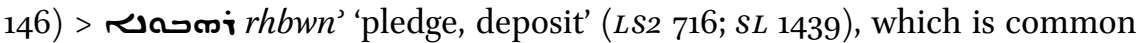
from the fourth century onward in Syriac. This spelling reflects the older Attic pronunciation. ${ }^{110}$ Medial $\rho \dot{\rho}$ is represented by the Syriac alveolar trill $r$ without $h$ in the following words:

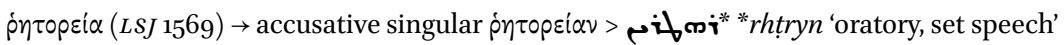
(5th cent. Julian Romance, 99.4 [ms. م م w htryn] [ed. G. Hoffmann, Iulianos der Abtruennige. Syrische Erzaehlungen (Leiden: Brill, 1880)]; only here; LS2 727; SL 1441).

105 The spelling refirtyn' also occurs in later literature.

106 In his Letter on Syriac Orthography, Ya'qub of Edessa (d. 708) refers to writings of $\dot{p}$ with $r h$ as 'according to ancient custom' (mettol m'ayyduto 'attiqto) (ed. G. Phillips, A Letter by Mār Jacob, Bishop of Edessa on Syriac Orthography [London: Williams and Norgate, 1869], p. 6.7-10).

107 Brock, 'Greek Words in Syriac: Some General Features', p. 256; Harviainen, 'On the Loss of the Greek /h/ and the So-called Aspirated Rhō', p. 66.

108 Allen, Vox Graeca, pp. 44-45.

109 Harviainen, 'On the Loss of the Greek /h/ and the So-called Aspirated Rhō', pp. 29-32.

110 Again, in his Letter on Syriac Orthography, Yaqqub of Edessa (d. 708) refers to writings of $p \dot{p}$ with $r h$ as 'according to ancient custom' (mettol m'ayyduto 'attiqto) (ed. Phillips, A Letter by Mār Jacob, Bishop of Edessa on Syriac Orthography, p. 6.7-10). 


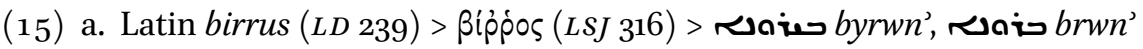
'toga, cloak, patriarch's chlamys' (5th cent. Life of Rabbula, 184.26 [ed. Overbeck, S. Ephraemi Syri Rabulae episcopi Edesseni Balaei aliorumque Opera selecta, 157-248]; LS2 69, 97; SL 143, 187)

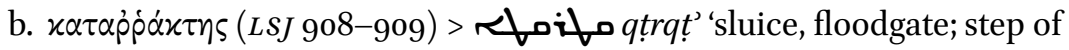
stairs' (Bible 1 Kgs 6.8; LS2 664; SL 1359)

The representation of $\dot{p} \dot{p}$ by Syriac $r$ (without $h$ ) reflects the later Koinē pronunciation after the allophonic realisation was lost. It should be noted that the

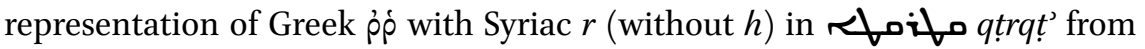
the Old Testament Peshițta does not necessarily reflect the date of composition (ca. 200), but rather may be due to a scribal update in the manuscripts, the earliest of which stem from the sixth century.111

Various representations of $\dot{\rho} \dot{p}$ are attested for $\pi \alpha \dot{\rho} \dot{p} \eta \sigma i \alpha$ (LSJ 1344). Table 1 provides a diachronic synopsis of these. In addition to $r h$ and $r($ without $h$ ), Greek $\dot{\rho} \dot{p}$ is represented by Syriac $r r$ in this word. This is an unusual representation of Greek gemination in Syriac. ${ }^{112}$ Thus, it is likely a reflection of the allophonic realisation of $\dot{p} \dot{p}$.

TABLE $1 \quad$ Diachronic synopsis of spellings of $\pi \alpha \rho j \rho j \eta \sigma^{\prime} \alpha$ in Syriac ${ }^{113}$

\begin{tabular}{|c|c|c|}
\hline $\begin{array}{l}\text { Pre-4th } \\
\text { cent. }\end{array}$ & $\begin{array}{l}\text { Old Syriac Gospels } \\
\text { Acts of Thomas } \\
(\text { ca. 200-250 CE) }\end{array}$ & 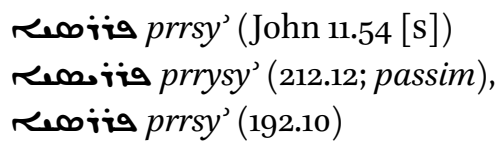 \\
\hline
\end{tabular}

4th cent. Demonstrations by Aphrahat (fl. 337-345)

Reمmia prhsy' (1.545.12)

Memro on our Lord by Ephrem r.omiจ prhsy' (11.24; 46.21) (d. 373)

111 For further discussion, see the comments in Butts, Syriac in Its Greco-Roman Context, §5.1 with n. 6.

112 For the representation of Greek gemination in Syriac, see Butts, Syriac in Its Greco-Roman Context, $§ 5 \cdot 2.8$.

113 The following editions were used: Old Syriac Gospels, ed. G.A. Kiraz, Comparative edition of the Syriac Gospels (Leiden: Brill, 1996); the Acts of Thomas, ed. Wright, Apocryphal Acts of the Apostles; Demonstrations by Aphrahaț, ed. Parisot, Aphraatis Sapientis Persae Demonstrationes; Memro on our Lord by Ephrem, ed. E. Beck, Des heiligen Ephraem des 
TABLE 1 Diachronic synopsis of spellings of $\pi \alpha p j p \eta \sigma i \alpha$ in Syriac (cont.)

5th cent. Teaching of Addai (ca. 420)

Reomis prhsy' (46.1; 50.18)

Julian Romance (5th cent.) reomia prhsy' (14.7; passim) Life of Rabbula (ca. 450) rलकाi prhsy' (186.13; 198.26)

6th cent. Lives of Eastern Saints م⿻上丨iف prhsy' (23.2, 12; passim) by Yuhanon of Ephesus

(d. ca. 589)

Life of Yuhanon of Tella by Eliya remina p'rsy' (77.12) (mid-6th cent.)

7th cent. Part 3 by Ishaq of Nineveh remoia prhsy' (99.9, 14) (late 7 th cent.) Life of Marutha by Denḥa Rowiia prrsy' (76.9) (d. 649)

Letter on Syriac Orthography by Ya'qub of Edessa (d. 708)

\section{Greek $\sigma$}

Greek $\sigma$ was a voiceless alveolar fricative /s/ in Attic Greek as well as in the Koinē Greek of the Roman and Byzantine periods. ${ }^{114}$ It is typically represented

Syrers Sermo de Domino Nostro (csco, 270-271, Louvain: Peeters, 1966); Teaching of Addai, ed. G. Howard, The Teaching of Addai (Chico: Scholars Press, 1981); Julian Romance, ed. Hoffmann, Iulianos der Abtruennige; Life of Rabbula, ed. Overbeck, S. Ephraemi Syri Rabulae episcopi Edesseni Balaei aliorumque Opera selecta, pp. 159-209; Lives of Eastern Saints by Yuhanon of Ephesus, ed. E.W. Brooks, John of Ephesus. Lives of the Eastern Saints, 1-3 (PO, 17.1; 18.4; 19.2, Paris: Brepols, 1923-1925); Life of Yuhanon of Tella by Eliya, ed. Brooks, Vitae virorum apud Monophysitas celeberrimorum, pp. 29-95; Part 3 by Ishaq of Nineveh, ed. S. Chialà, Isacco di Ninive. Terza collezione (csco, 637-638, Louvain: Peeters, 2011); Life of Marutha by Denha, ed. F. Nau, Histoires d'Ahoudemmeh et de Marouta (PO, 3.1, Paris: Brepols, 1905) pp. 52-96; Letter on Syriac Orthography by Ya'qub of Edessa, ed. Phillips, A Letter by Mār Jacob, Bishop of Edessa on Syriac Orthography.

114 For Attic, see Allen, Vox Graeca, pp. 45-46; Woodard, 'Attic Greek', p. 616; for Koinē, see Gignac, A Grammar of the Greek Papyri of the Roman and Byzantine Periods, vol. 1, p. 178; Mayser, Grammatik der griechischen Papyri aus der Ptolemäerzeit, p. 176. 
by the Syriac voiceless alveolar fricative $s,{ }^{115}$ e.g., dे $\sigma \pi$ i (LSJ 259) >

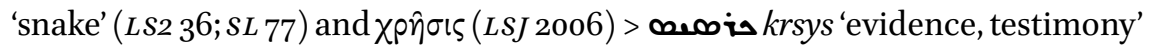
(LS2 348; SL 652).

Greek $\sigma$ is represented by the emphatic alveolar fricative $s$ in the following words:

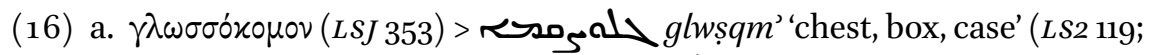
SL 234), but more commonly حلم glwsqm' (LS2 119; SL 234) as well as rarely ratool glwstm' (LS2 119; SL 233-234)

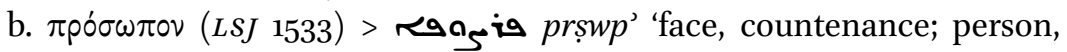
party' (LS2 605; SL 1249-1250)

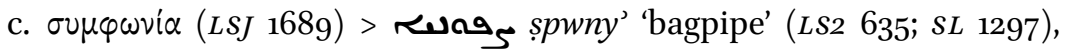
already in Aramaic of Daniel sumponys (Dan. 3.5, 15), sypnyh (Dan. 3:10 [k]), supponys (Dan. 3:10 [q]) (HALOT 1937-1938) without emphatic ș

In each of these cases, the emphatic ș is due to the assimilation of [+emphatic] in the context of another emphatic consonant, including the "emphatic" $p(<$ Greek $\pi$ ).

Greek $\sigma$ is represented by the voiced dental fricative $z$ in the following cases:

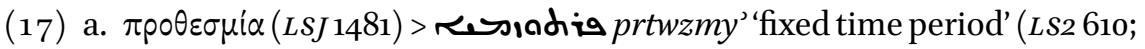
$S L 1256)$, with an alternative spelling of rescodiais prwtsmy' (LS2 610; $S L$ 1235)

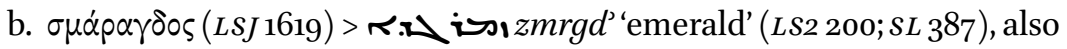
in Samaritan Aramaic zmrgdy (DSA 234); Christian Palestinian Aramaic zmrgd (DCPA 111; LSP 56); Jewish Palestinian Aramaic zmrgd (DJPA 179), but note also r.

c. $\sigma \mu^{\prime} \lambda \eta$ (LSJ 1619) > Rل rismly' 'small knife, scalpel' (LS2 199; $S L$ 385), also in TgJon 'uzmil (Jer 36:23); Jewish Palestinian Aramaic 'wzmyl (DJPA 38); Late Jewish Literary Aramaic ' $z m l$ (TgJob 16:9; Jastrow 46)

This representation is due to an assimilation of $\sigma$ to $\zeta$ before $\mu$ in the Greek source, a change that is well attested in Greek documents from Egypt. ${ }^{116}$

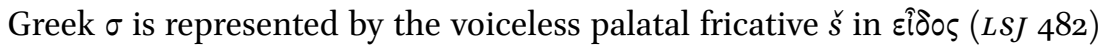
$>$ > r. ' 'dšs 'form in the Platonic sense; species, kind; character, nature; fruit'

115 Kiraz, Türrāṣ Mamllā, §6o3-604.

116 Gignac, A Grammar of the Greek Papyri of the Roman and Byzantine Periods, vol. 1, pp. 120121; Mayser, Grammatik der griechischen Papyri aus der Ptolemäerzeit, p. 177. 
$(L S 26 ; S L 11)$. This representation also occurs in Mandaic ațšia 'crops, fruits' ( $M D$ 14). ${ }^{117}$

An initial consonant cluster that begins with $\sigma$ in Greek may be optionally represented in Syriac with a prothetic voiceless glottal stop, as in the following representative examples: ${ }^{118}$

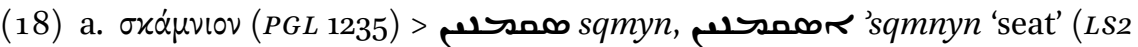
$37,495 ; S L 79,1040)$

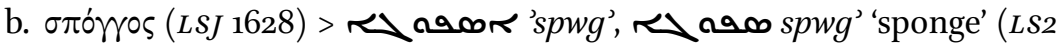
$35 ; S L 75)$

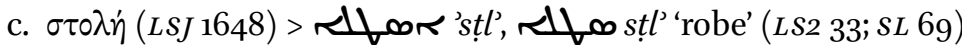

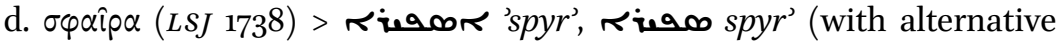
orthographies) 'sphere; circle; ball; pine cone; cake' (LS2 36, 493; SL 76, 1031)

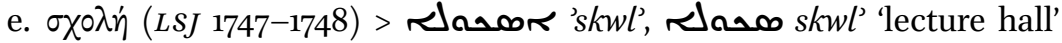
(LS2 34, 474; SL 73, 1008)

As these examples illustrate, the prothetic voiceless glottal stop is optional. The appearance of the voiceless glottal stop in these words represents an inner Syriac (or better: Aramaic) development according to which a consonant cluster beginning with a sibilant optionally occurs with a prothetic glottal stop,

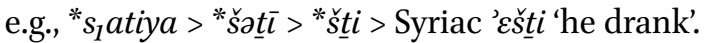

\section{$15 \quad$ Greek $\tau$}

Greek $\tau$ was a voiceless unaspirated dental stop / $\mathrm{t} /$ in Attic Greek as well as in the Koinē Greek of the Roman and Byzantine periods. ${ }^{119}$ Greek $\tau$ is typically represented in Syriac by the emphatic dental stop $t,^{120}$ e.g., $\pi i \tau \tau \dot{\alpha}$ xı $10 \nu$ (LSJ 1409) > r

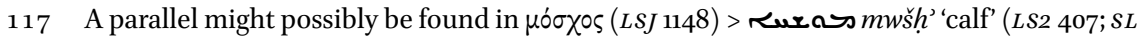
731), though the correspondence of Greek $\chi$ with Syriac $h$ would also be irregular.

118 Brock, 'Greek and Latin Words in Palmyrene Inscriptions', p. 24; Kiraz, Tūrrāṣs Mamllā, § 90; Nöldeke, Compendious Syriac Grammar, §51.

119 For Attic, see Allen, Vox Graeca, pp. 16-17; Woodard, 'Attic Greek', p. 616; for Koinē, see Gignac, A Grammar of the Greek Papyri of the Roman and Byzantine Periods, vol. 1, p. 178.

120 Brock, 'Greek Words in Syriac: Some General Features', p. 255; Kiraz, Tūrrāṣ Mamllā, §6o3604; Voigt, 'Das emphatische p des Syrischen', p. 528. 


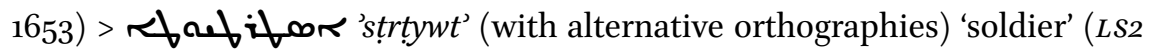
$34,469 ; S L 71,998)$.

Greek $\tau$ is represented with Syriac $t$, which was either a voiceless dental stop or a voiceless dental fricative, in several different groups of words. First, this representation occurs in words in which $\tau$ follows $\sigma: !^{21}$

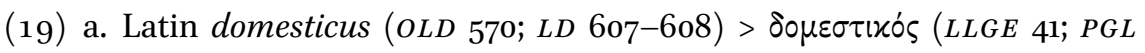

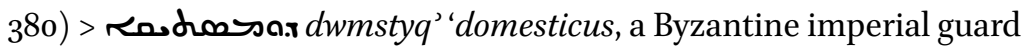

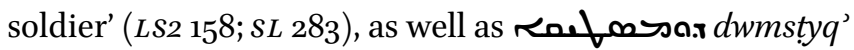

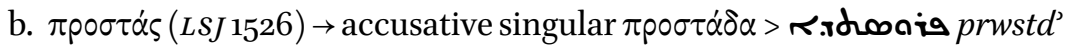
'doorpost, lintel; vestibule, portico' (LS2 603; SL 1233)

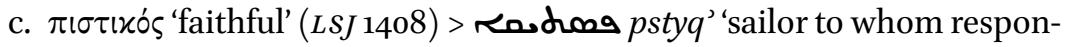
sibility for a ship is entrusted' (LS2 585; SL 1215-1216)

The representation of Greek $\tau$ with Syriac $t$ in these cases is due to a change of Greek $\tau$ to $\theta$ after $\sigma$ in the Greek source, a change which is attested in Greek documents from Egypt as well as from Syria and Mesopotamia. ${ }^{122}$ There are several additional words in which Greek $\tau$ is represented by Syriac $t$ :

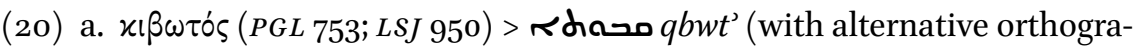
phies) 'box; ark; chest; Ark of the Covenant; Noah's Ark' (LS2 44;SL 1306)

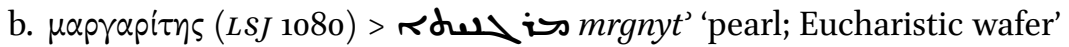
(LS2 402; SL 826)

c. $\mu \eta \lambda \omega \tau \tau^{\prime}(L S J 1127)$ > RdL mylt' 'carpet; covering; pillow' (LS2 383; SL $\left.75^{2}\right)$

In each of these cases, the irregular correspondence likely has a morphological motivation, i.e., $t$ is the Syriac feminine ending ${ }^{*}-(a) t$. Finally, Greek $\tau$ is represented with Syriac $t$ in $\tau \dot{\gamma} \gamma \mu \alpha(L S J 1752)>$ > $\phi$ tgm 'order, class; command, precept; troop, cohort' ( $L S 2$ 816; $S L$ 185, 1623). ${ }^{123}$ The representation of Greek $\tau$ with Aramaic $t$ in this word is already found in Palmyrene Aramaic tgm' 'asso-

121 See also $\sigma \tau \alpha \tau \dot{\eta} \rho(L S J$ 1634) > Ridhor 'styr', Ridoor 'str' 'stater, coin, weight' (LS2 38; SL 80 ), though the immediate source may be Iranian and not Greek (so $S L 80$ ). For immediate versus ultimate source, see n. 22 above.

122 For Egypt, see Gignac, A Grammar of the Greek Papyri of the Roman and Byzantine Periods, vol. 1, p. 87; Mayser, Grammatik der griechischen Papyri aus der Ptolemäerzeit, p. 154; for Syria and Mesopotamia, see, e.g., $\chi \alpha \tau \varepsilon \sigma \theta \dot{\theta} \theta \eta \nu$ for $\chi \alpha \tau \varepsilon \sigma \tau \alpha \dot{\theta} \eta \nu$ (P.Dura 46.r5 [early 3rd]); $\dot{\alpha} \varphi \varepsilon i \sigma \theta \alpha \sigma \theta \alpha \mathrm{l}$ for $\dot{\alpha} \varphi i \sigma \tau \alpha \sigma \theta \alpha \mathrm{l}$ (P.Dura 31.int.7, ext.33 [204]).

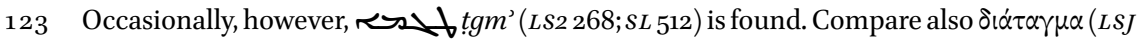


ciation' (PAT 418). Brock suggests that this representation is due to assimilation of [-emphatic].124

\section{$16 \quad$ Greek $\varphi$}

Greek $\varphi$ was an aspirated voiceless bilabial stop $/ \mathrm{p}^{\mathrm{h}} /$ in Attic Greek. ${ }^{125}$ During the Roman period, it developed into a voiceless bilabial fricative $/ \phi /,{ }^{126}$ which became the established pronunciation in the Byzantine period. Greek $\varphi$ is typically represented in Syriac by $p,{ }^{127}$ which was realised as a voiceless bilabial stop or a voiceless bilabial fricative, e.g., ḋó $\varphi \alpha \sigma ı \zeta\left(L S J 225^{-226}\right)>$ >

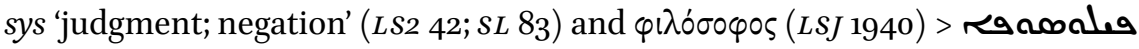
pylwswp' 'philosopher' (LS2 575; SL 1187).

\section{$17 \quad$ Greek $\chi$}

Greek $\chi$ was an aspirated voiceless velar stop $/ \mathrm{k}^{\mathrm{h}} /$ in Attic Greek. ${ }^{128}$ During the Roman period, it developed into a voiceless velar fricative $/ x /{ }^{129}$ which became the established pronunciation in the Byzantine period. Greek $\chi$ is typically represented by Syriac $k{ }^{130}$ which was realised as a voiceless velar stop or a

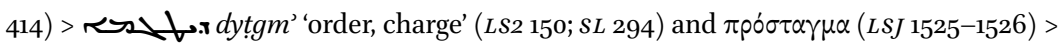

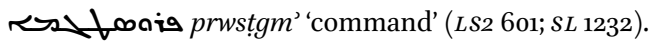

124 S.P. Brock, 'Some Aspects of Greek Words in Syriac', in A. Dietrich (ed.), Synkretismus im syrisch-persischen Kulturgebiet (Göttingen: Vandenhoeck \& Ruprecht, 1975) pp. 80-108 (83 n. 20) (reprinted in his Syriac Perspectives on Late Antiquity [London: Variorum Reprints, 1984], IV); 'Greek Words in Syriac: Some General Features', pp. 255-256; 'Greek and Latin Words in Palmyrene Inscriptions', p. 22.

125 Allen, Vox Graeca, pp. 18-26; Woodard, 'Attic Greek', p. 616.

126 Gignac, A Grammar of the Greek Papyri of the Roman and Byzantine Periods, vol. 1, pp. 64, $86-96,178$.

127 Brock, 'Greek Words in Syriac: Some General Features', p. 255; Kiraz, Tūrrāṣ Mamllā, §603-604; Nöldeke, Compendious Syriac Grammar, §25; Voigt, 'Das emphatische p des Syrischen', pp. 528-529.

128 Allen, Vox Graeca, pp. 18-26; Woodard, 'Attic Greek', p. 616.

129 Gignac, A Grammar of the Greek Papyri of the Roman and Byzantine Periods, vol. 1, pp. 64, 86-96, 178.

130 Brock, 'Greek Words in Syriac: Some General Features', p. 255; Kiraz, Tūrrāṣ Mamllā, §603-604; Nöldeke, Compendious Syriac Grammar, § 25; Schall, Studien über griechische Fremdwörter im Syrischen, pp. 42-44; Voigt, 'Das emphatische p des Syrischen', p. $5^{28 .}$ 


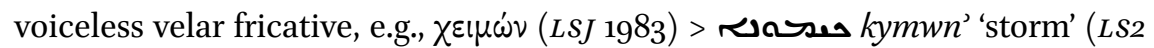

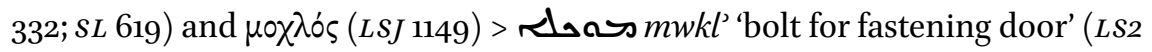
$385 ; S L$ 724).

Greek $\chi$ is represented by the emphatic velar stop $q$ in the following words: 131

(21) a. $\chi \alpha \lambda x \eta \delta \delta$ ' (LSJ 1973) > ص. م $q r k d n$ ' 'chalcedony' (LS2 696; SL 1411). This would not be the only irregular consonant correspondence in the word (see fn. $5^{8}$ above).

b. $\chi \alpha p \alpha \dot{\alpha} x \omega \mu \alpha(L S J 1977)>$ > ملمه qlqwm' 'siege engines, entrenchments' (LS2 670; SL 1375), compare the expected correspondence in TgJon krqwm' (1Sm 26:7; Jastrow 669) and Late Jewish Literary Aramaic krqwm' (TgJob 20:24; Jastrow 669), as well as Jewish Palestinian Aramaic krkwm (DJPA 270), where however the correspondence of $x$ is irregular

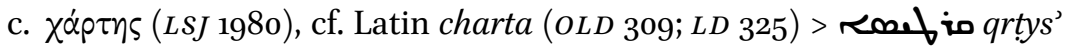
'sheet of paper; papyrus' (LS2 695; $S L$ 1405-1406), with the same correspondence in Jewish Palestinian Aramaic qrtys (DJPA 269) and Jewish Palestinian Aramaic qrtys (DJPA 269), though roof i krtys' (LS2 344; $S L$ 650) also occurs in Syriac, with the same correspondence in Jewish Palestinian Aramaic krtys (DJPA 269) and Christian Palestinian Aramaic krtys (DCPA 185)

This seemingly irregular correspondence is due to a change of $\chi$ to $x$ before a liquid in the Greek source, a change that is attested in Greek documents from Egypt. ${ }^{132}$

18 Greek $\psi$

Greek $\psi$ is a monograph for the voiceless unaspirated bilabial stop $\pi$ and the voiceless alveolar fricative $\sigma$ in Attic Greek as well as in the Koinē Greek of the Roman and Byzantine periods. ${ }^{133}$ It is represented in Syriac by two

\footnotetext{
131 See also Schall, Studien über griechische Fremdwörter im Syrischen, 232.

132 Gignac, A Grammar of the Greek Papyri of the Roman and Byzantine Periods, vol. 1, pp. 8696, esp. top of 91; Mayser, Grammatik der griechischen Papyriaus der Ptolemäerzeit, pp. 144145 .

133 For Attic, see Allen, Vox Graeca, pp. 59-6o; Woodard, 'Attic Greek', p. 616; for Koinē, see Gignac, A Grammar of the Greek Papyri of the Roman and Byzantine Periods, vol. 1, pp. 141142; Mayser, Grammatik der griechischen Papyri aus der Ptolemäerzeit, p. 185.
} 
consonants: $p$, which was realised as a voiceless bilabial stop or a voiceless bilabial fricative, and the voiceless alveolar fricative $s,{ }^{134}$ e.g., $\psi \eta^{\prime} \varphi \iota \sigma \mu \alpha$ (LSJ

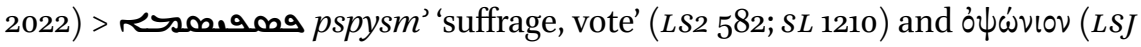

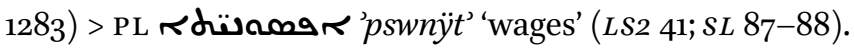

\section{Greek Word-initial spiritus asper}

Greek words with initial spiritus asper were realised with an initial voiceless glottal fricative /h/ in Attic Greek, ${ }^{135}$ e.g., öpos /horos/ 'boundary' (LSJ 12551256). During the Late Antique period, spiritus asper in word initial position ceased to be pronounced. ${ }^{136}$ Greek spiritus asper is usually represented with

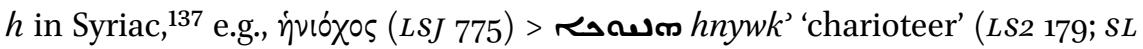

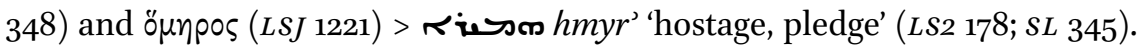
The representation of Greek spiritus asper with Syriac $h$ reflects the earlier Attic pronunciation. ${ }^{138}$ In some manuscripts, the initial $h$ is marked with a sub-linear dot to indicate that it represents spiritus asper, ${ }^{139}$ and perhaps that it should not be pronounced.

Greek spiritus asper is, however, not represented with $h$ in the following words: ${ }^{140}$

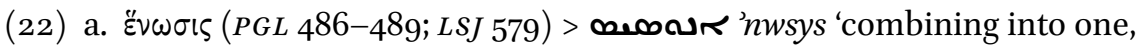
union' (6th cent. Yuhanon of Ephesus, Ecclesiastical History, Part 3, 27.23 [ed. Brooks, Iohannis Ephesini. Historiae Ecclesiasticae]; LS2 30; $S L 60)$

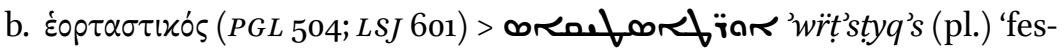
tal' (7th cent. Ya'qub of Edessa, Letter 13, to Yuhanon the Stylite of Litarba

134 Kiraz, Türrāṣ Mamllā, § 603-604; Voigt, 'Das emphatische p des Syrischen', pp. 529-531.

135 Allen, Vox Graeca, pp. $5^{2-56}$. It has also been reconstructed as a voiceless laryngeal fricative / $\mathrm{h} /$ (see, e.g., Harviainen, 'On the Loss of the Greek / $\mathrm{h} /$ and the So-called Aspirated Rhō', p. 1 with n. 2).

136 Harviainen, 'On the Loss of the Greek /h/ and the So-called Aspirated Rhō'.

137 Brock, 'Greek Words in Syriac: Some General Features', p. 256; Harviainen, 'On the Loss of the Greek /h/ and the So-called Aspirated Rhō', pp. 59-61.

138 In his Letter on Syriac Orthography, Yaqub of Edessa (d. 708) refers to representations of spiritus asper with $h$ in Syriac as 'according to ancient custom' (metțol m'ayydutu sattiqț) (ed. Phillips, A Letter by Mār Jacob, Bishop of Edessa on Syriac Orthography, p. 6.6-10).

139 Kiraz, Türrāṣ Mamllā, § 203; Segal, The Diacritical Point and the Accents in Syriac, p. 26.

140 Brock, 'Greek Words in Syriac: Some General Features', p. 256; Brock, 'Greek Words in Syriac: Some General Features', pp. 61-63. 
on eighteen biblical questions, 8.15 [ed. W. Wright, 'Two Epistles of Mār Jacob, Bishop of Edessa', Journal of Sacred Literature and Biblical Record 10 (1867), pp. 430-46o]; only here; $L S 2$ 48; $S L 9)^{141}$

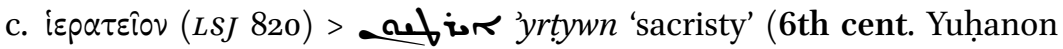
of Ephesus, Ecclesiastical History, Part 3, 12.16 [ed. Brooks, Iohannis Ephesini. Historiae Ecclesiasticae]; LS2 16; $S L$ 38;)

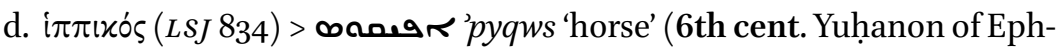
esus, Ecclesiastical History, Part 3, 114.26 [ed. Brooks, Iohannis Ephesini. Historiae Ecclesiasticae]; LS2 42; SL 87)

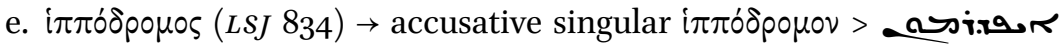
'ypdrmwn 'hippodrome' (6th cent. Yuhanon of Ephesus, Ecclesiastical History, Part 3, 151.7 [ed. Brooks, Iohannis Ephesini. Historiae Ecclesiasticae]; $L S 2$ 40; $S L 81)$

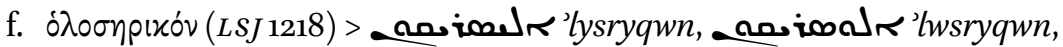
كملمنمف 'Isyryqwn 'garment entirely of silk' (6th cent. Yuhanon of Ephesus, Ecclesiastical History, Part 3, 139.27 [ed. Brooks, Iohannis Ephesini. Historiae Ecclesiasticae]; Lives of the Eastern Saints, 538.10; 540.10 [ed. Brooks, John of Ephesus. Lives of the Eastern Saints]; LS2 22; $S L$ 49)

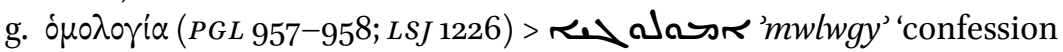
of faith' (6th cent. Yuhanon of Ephesus, Ecclesiastical History, Part 3, 117.26; 131.20 [ed. Brooks, Iohannis Ephesini. Historiae Ecclesiasticae]; $L S 2$ 25; SL 53), note already Palmyrene ' $m l g y$ ' (PAT 339-340; see also Brock, 'Greek and Latin Words in Palmyrene Inscriptions', p. 19)

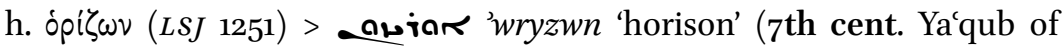
Edessa, Scholia, 4.150.43 [ed. P. Benedictus, Sancti patris nostri Ephraem Syri Opera omnia quae exstant Graece, Syriace, Latine (Rome: J.M.H. Salvioni, 1732-1746)]; Hexaemeron, 172.2.23 [ed. J.-B. Chabot, Iacobi Edesseni Hexaemeron (csco 92, 97, Louvain: Peeters, 1953)]; Severos Sebokht, Treatise on the Astrolabe, 84.11 [PL oه wasoina 'wrwyzwnțws] [ed. F. Nau, 'Le traité sur l' astrolabe plan de Sévère Sébokt', JA 9.13 (1899), pp. 56-101, 238-303]; LS2 47; SL 22)

In all of these cases, the word in question is not attested until the sixth or seventh century in Syriac. The representation of Greek spiritus asper with the Syriac voiceless glottal stop 'reflects the later Koinē pronunciation.

141 The spelling or مarforfinar 'writ'stywq's, which is given in $s L 9$, is not found in the edition of Wright. 
In addition, occasionally, two forms of a word are attested in Syriac, one with initial $h$ and another with initial ':142

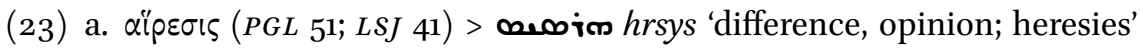
(Pre-4th cent. Book of the Laws of the Countries, 28.14; 36.17, 36.20 [ed. H.J.W. Drijvers, The Book of the Laws of the Countries (Assen: Van Gorcum, 1965)]; LS2 90, 184; SL 180, 355;) vs. ceoir 'rsys (6th cent. Life ofJohn bar Aphtonia, 23.1 [ed. F. Nau, Vie de Jean bar Aphtonia: Texte syriaque (Bibliothèque hagiographique orientale 2, Paris, 1902)]; LS2 51; $S L$ 103)

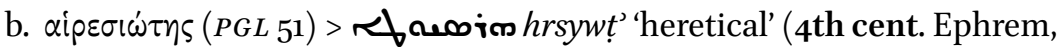
Prose Refutations, Discourse 1, 47.16 [ed. Overbeck, S. Ephraemi Syri Rabulae episcopi Edesseni Balaei aliorumque Opera selecta, pp. 21-58]; LS2 184; SL 355) vs. R م tary on Matthew and Luke, 28.26 [ed. J.W. Watt, Philoxenus of Mabbug. Fragments of the Commentary on Matthew and Luke (csco 392-393, Louvain: Peeters, 1978)]; LS2 51; SL 103)

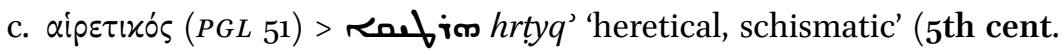
Julian Romance, 125.20 [ed. Hoffmann, Iulianos der Abtruennige]; Narsai, Memre on Biblical Themes, 17.459; 18.490, 495, 506 [ed. J. Frishman, The Ways and Means of the Divine Economy. An Edition, Translation and Study of Six Biblical Homilies by Narsai (Ph.D. Diss., Leiden, 1992)]; Life of Rabbula, 171.9; 193.11; 194.10, 20 [ed. Overbeck, S. Ephraemi Syri Rabulae episcopi Edesseni Balaei aliorumque Opera selecta, pp. 157-248]; Ls2 183; sL 354) vs. Rم rif 'rtyq' (6th cent. Yuhanon of Ephesus, Lives of the Eastern Saints, 601.10 [ed. Brooks, John of Ephesus. Lives of the Eastern Saints ]; LS2 48; SL 98)

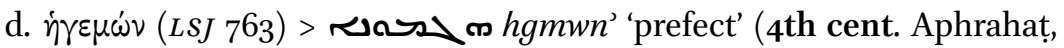
Demonstrations, 1.973.6 [ed. Parisot, Aphraatis Sapientis Persae Demonstrationes]; Book of Steps, 645.20; 648.3 [ed. Kmosko, Liber Graduum]; LS2 171; SL 340) vs. كمحك 'ygmwn' 'prefect' (4th cent. Book of Steps, 648.15 [ed. Kmosko, Liber Graduum]; LS2 4; SL 31)

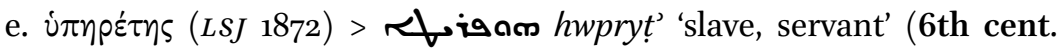
Yuhanon of Ephesus, Ecclesiastical History, Part 3, 64.2 [ed. Brooks, Iohannis Ephesini. Historiae Ecclesiasticae]; LS2 182; $S L$ 338) vs. ـ

142 Brock, 'Greek Words in Syriac: Some General Features', pp. 203-204. For additional examples involving translation literature, see Butts, Syriac in Its Greco-Roman Context, p. 76, n. 41. 
siastical History, Part 3, 61.23; 64.20 [ed. Brooks, Iohannis Ephesini. Historiae Ecclesiasticae]; LS2 43; SL 89)

Again, there is a clear diachronic tendency: it is only after the fifth century that spiritus asper ceased to be consistently represented with $h$. The one exception

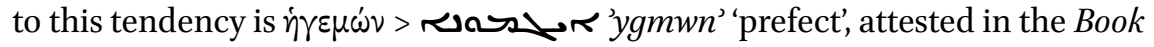
of Steps. This spelling in the Book of Steps, however, probably reflects the date of the manuscript (ca. 12th cent.) and not the supposed date of composition (ca. 400). ${ }^{143}$ This seems especially likely since the earlier spelling hgmwn' also occurs in this text and even within the very same passage (648.3; see also 645.20). Moreover, in the 7 th- or 8th-cent. ms. Jerusalem Syr. 180, which was not used in the edition, but which the editor was later able to collate, the spelling with initial $h$ is found instead of initial 'at 648.15, again suggesting that the later spelling is due to transmission history. ${ }^{144}$

\section{Conclusion}

The representation of Greek consonants in Syriac is remarkably regular. In the vast majority of cases, each Greek consonantal phoneme is represented by a single consonant in Syriac. These correspondences are summarised in Table 2. Correspondences that deviate from this chart are usually the result of one of two causes. First, a Koinē form of Greek likely served as the source for some of the words that prima facie seem to exhibit irregular correspondences. This is, for instance, the case with the initial consonant of fلح gwbrnyț 'helmsman, pilot' in Aphrahaț's Demonstrations (1.612.2), which does

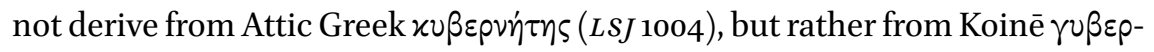

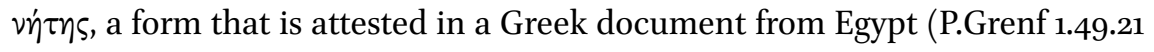
$[220 / 221 \mathrm{CE}])$. Second, some of the seemingly irregular correspondences are due to secondary developments. This is, for instance, the case with $\sigma i v \delta \omega \nu$ ( $L S J$ 1600) > كaro $s d w n$ ' 'fine linen cloth' (LS2 460; $S L$ 970), which results from the regressive assimilation of $n$ to $d$ in Syriac. Excluding cases subsumed under these two categories, there are very few irregular correspondences in the integration of consonants in Greek loanwords in Syriac.

143 For arguments against the traditional dating of this text to the fourth century, see K. Smith, 'A Last Disciple of the Apostles. The "Editor's" Preface, Rabbula's Rules, and the Date of the Book of Steps', in K.S. Heal and R.A. Kitchen (eds.), Breaking the Mind. New Studies in the Syriac 'Book of Steps' (Washington, DC: CUA Press, 2014) pp. 72-96.

144 See Kmosko, Liber Graduum, p. ccciv (s.v. 648.15). 
TABLE 2 Representation of Greek consonants in Syriac

\begin{tabular}{|c|c|c|c|}
\hline Greek & Syriac & Syriac & Greek \\
\hline$\beta$ & $\checkmark b$ & $r^{\prime}$ & $\begin{array}{l}\text { spiritus asper } \\
\text { (initial) }\end{array}$ \\
\hline$\gamma$ & $\gg g$ & $\neg b$ & $\beta$ \\
\hline$\delta^{\gamma / \mathrm{y} /}$ & $\frac{n}{d}$ & $\rightarrow g$ & $\begin{array}{l}\gamma \\
\delta\end{array}$ \\
\hline$\zeta$ & $1 z$ & m $h$ & $\begin{array}{l}\text { spiritus asper } \\
\text { (initial) }\end{array}$ \\
\hline$\theta$ & $d t$ & $1 z$ & $\zeta$ \\
\hline$x$ & ه & $\downarrow t$ & $\tau$ \\
\hline$\lambda$ & $J i$ & $n k$ & $\chi$ \\
\hline$\mu$ & $>m$ & $\infty$ ass & $\xi$ \\
\hline$v$ & $n$ & \rfloor $l$ & $\lambda$ \\
\hline$\xi$ & $\infty$ a ks & $>m$ & $\mu$ \\
\hline$\pi$ & $a p$ & $n$ & $\nu, \gamma / \mathrm{y} /$ \\
\hline$\rho$ & ir & $\boldsymbol{\infty} s$ & $\sigma$ \\
\hline$\dot{\rho}-$ & कi $r h$, ir & $\theta p$ & $\pi, \varphi$ \\
\hline$\dot{\rho} \dot{\rho}$ & कi $r h$, ir & $\infty p s$ & $\psi$ \\
\hline$\sigma$ & $\infty s$ & q & $x$ \\
\hline$\tau$ & $\downarrow t$ & ir & $\rho$ \\
\hline$\varphi$ & a $p$ & wirh & $\dot{\rho}-, \dot{\rho} \dot{\rho}$ \\
\hline$\chi$ & $n k$ & $d t$ & $\theta$ \\
\hline$\psi$ & $\infty p s$ & & \\
\hline $\begin{array}{l}\text { spiritus asper } \\
\text { (initial) }\end{array}$ & $\boldsymbol{m} h, \boldsymbol{\sim}^{\prime}$ & & \\
\hline
\end{tabular}

21 Abbreviations of Lexicographical Resources

$B K \quad$ A. de. Biberstein-Kazimirski, Dictionnaire arabe-français (Paris: Théophile Barrois, 186o).

CDG W. Leslau, Comparative Dictionary ofGe'ez(ClassicalEthiopic)(Wiesbaden: Harrassowitz, 1987).

DCPA M. Sokoloff, A Dictionary of Christian Palestinian Aramaic (OLA, 234, Louvain: Peeters, 2014).

DJBA M. Sokoloff, A Dictionary ofJewish Babylonian Aramaic of the Talmudic and Geonic Periods (Ramat-Gan: Bar Ilan University Press, 2002). 
DJPA M. Sokoloff, A Dictionary ofJewish Palestinian Aramaic of the Byzantine Period (Ramat-Gan: Bar Ilan University Press, 2nd ed., 2002).

DSA A. Tal, A Dictionary of Samaritan Aramaic (Leiden: Brill, 2000).

GLBRP E.A. Sophocles, Greek Lexicon of the Roman and Byzantine Periods (New York: C. Scribner's Sons, 1900).

HALOT L. Koehler and W. Baumgartner (revised by W. Baumgartner and J.J. Stamm), The Hebrew and Aramaic Lexicon of the Old Testament (Leiden: Brill, 1994-2000).

Jastrow M. Jastrow, Dictionary of the Targumim, the Talmud Babli and Yerushalmi, and the Midrashic Literature (New York: G.P. Putnam's Son, 1886-1903).

Lane $\quad$ E.W. Lane, An Arabic-English Lexicon (London: Williams and Norgate, 1863-1893).

LD C.T. Lewis and C. Short, A Latin Dictionary (Oxford:Clarendon Press, 1969).

LLGE Sergio Daris, Il lessico latino nel greco d'egitto (Barcelona: Institut de Teologia fonamental, Seminari de Papirologia, 2nd ed., 1991).

LS2 C. Brockelmann, Lexicon Syriacum (Halis Saxonum: Sumptibus M. Niemeyer, 2nd ed., 1928).

LSJ H.G. Liddell and R. Scott (revised by H. Stuart Jones and R. McKenzie), A Greek-English Lexicon (Oxford: Oxford University Press, 1996).

LSJ Suppl. H.G. Liddell and R. Scott (revised by H. Stuart Jones and R. McKenzie; edited by P.G.W. Glare), Greek-English Lexicon. Revised Supplement (Oxford: Oxford University Press, 1996).

LSP F. Schulthess, Lexicon Syropalaestinum (Berolini: G. Reimer, 1903).

$M D \quad$ E.S. Drower and R. Macuch, A Mandaic Dictionary (Oxford: Clarendon Press, 1963).

OLD P.G.W. Glare, Oxford Latin Dictionary (Oxford: Clarendon Press, 1982).

PAT D.R. Hillers and E. Cussini, Palmyrene Aramaic Texts (Baltimore: Johns Hopkins University Press, 1996).

PGL G.W.H. Lampe, A Patristic Greek Lexicon (Oxford: Clarendon Press, 1961).

SL M. Sokoloff, A Syriac Lexicon. A Translation from the Latin, Correction, Expansion, and Update of C. Brockelmann's Lexicon Syriacum (Winona Lake: Eisenbrauns—Piscataway: Gorgias Press, 2009). 1901). 